\title{
Biotically constrained palaeoenvironmental conditions of a mid-Holocene intertidal lagoon on the southern shore of the Arabian Gulf: evidence associated with a whale skeleton at Musaffah, Abu Dhabi, UAE
}

\author{
J.R. Stewart ${ }^{\mathrm{a}, *}$, S. Aspinall ${ }^{\mathrm{b}}$, M. Beech ${ }^{\mathrm{c}}$, P. Fenberg ${ }^{\mathrm{d}, 1}$, P. Hellyer ${ }^{\mathrm{b}}$, N. Larkin ${ }^{\mathrm{e}}$, S.W. Lokier ${ }^{\mathrm{f}}$, F.G. Marx ${ }^{\mathrm{g}, \mathrm{h}}$, \\ M. Meyer ${ }^{\mathrm{i}}$, R. Miller ${ }^{\mathrm{j}}$, P.S. Rainbow ${ }^{\mathrm{k}}$, J.D. Taylor ${ }^{\mathrm{k}}$, J.E. Whittaker ${ }^{\mathrm{d}}$, K. Al-Mehsin', C.J. Strohmenger ${ }^{1,2}$ \\ ${ }^{a}$ School of Applied Sciences, Bournemouth University, Talbot Campus, Poole, Dorset BH12 5BB, UK \\ ${ }^{\mathrm{b}}$ P.O. Box 3790, Abu Dhabi, United Arab Emirates \\ ${ }^{c}$ Abu Dhabi Authority for Culture and Heritage (ADACH), P.O. Box 2380, Abu Dhabi, United Arab Emirates \\ ${ }^{\mathrm{d}}$ Department of Palaeontology, Natural History Museum, Cromwell Road, London SW7 5BD, UK \\ ${ }^{\mathrm{e}}$ Norwich Castle Museum and Art Gallery, Shirehall, Market Avenue, Norwich NR1 3JQ UK \\ ${ }^{\mathrm{f}}$ Petroleum Geosciences Department, The Petroleum Institute, P.O. Box 2533, Abu Dhabi, United Arab Emirates \\ ${ }^{g}$ Department of Geology, University of Otago, 360 Leith Walk, PO Box 56, Dunedin, Otago 9054, New Zealand \\ ${ }^{\mathrm{h}}$ Department of Earth Sciences, University of Bristol, Wills Memorial Building, Queen's Road, Bristol BS8 1RJ, UK \\ i Max Planck Institute for Evolutionary Anthropology, Deutscher Platz 6, D-04103 Leipzig, Germany \\ ${ }^{\mathrm{j}}$ Université de Liège, Service de Préhistoire, 7 place du XX août, bât. A1, B-4000 Liège, Belgium \\ ${ }^{k}$ Department of Zoology, Natural History Museum, Cromwell Road, London SW7 5BD, UK \\ ${ }^{1}$ Abu Dhabi Company for Onshore Oil Operations (ADCO), P.O. Box 270, Abu Dhabi, United Arab Emirates
}

\section{A R T I C L E I N F O}

\section{Article history:}

Received 28 May 2011

Received in revised form

9 September 2011

Accepted 9 September 2011

Available online $\mathrm{xxx}$

\begin{abstract}
A B S T R A C T
Whale remains (a left and right mandible, scapula, humerus and fragmentary radius and ulna as well as parts of the cranium and rostrum) belonging to a probable humpback whale (Megaptera cf. novaeangliae) were found in the well-described sabkha sequence exposed in the Musaffah Industrial Channel, Abu Dhabi, United Arab Emirates. More precisely, the whale remains were found in a series of sediments representing a range of lagoonal facies. The sediments surrounding the whale bones were age-dated at approximately $5200{ }^{14} \mathrm{C}$ yrs BP and are therefore interpreted to correspond to the previously documented late Flandrian sea-level peak, preceding a fall in sea-level which culminated in the supratidal sabkha overprint of the carbonates. Associated with the whale remains is an assemblage of molluscs, foraminifera and ostracods. Together with the inferred presence of sea grass and algae, these facies are interpreted to indicate a very shallow subtidal to intertidal lagoonal environment. Cirripede remains found associated with the skeleton were identified as those of the whale barnacle Coronula diadema and hence had their origins with the whale. Significantly, the low species diversity of microfossils suggests that higher salinities existed in the mid-Holocene lagoon than are present in modern counterparts. This is here inferred to be related to the onset of continental aridity in Arabia during the mid-Holocene.
\end{abstract}

(c) 2011 Elsevier Ltd. All rights reserved.

\section{Introduction}

In March 2006 Abu Dhabi National Oil Company (ADNOC) geologists Khalil Al-Mehsin and Bernard Pierson found a large bone eroding out of a sediment section on the edge of a man-made

\footnotetext{
* Corresponding author. Tel.: +44 (0) 1202 968178; fax: +44 (0) 1202965255.

E-mail address: jstewart@bournemouth.ac.uk (J.R. Stewart).

1 Present address: Department of Zoology, Oregon State University, Corvallis, OR 97331, USA.

2 Present address: ExxonMobil Research Qatar, Qatar Science and Technology Park, P.O. Box 22500, Doha, Qatar.
}

channel dug in the Musaffah Industrial Area, southwest of Abu Dhabi Island, United Arab Emirates (UAE) (Pierson et al., 2006, 2008) (Figs. 1 and 2). The bone has since been identified as part of a whale mandible. The sediments making up the canal wall form part of the well-known Holocene transgressive/regressive sequence, terminating in the formation of sabkha evaporites (gypsum and anhydrite). In this section approximately $1.20 \mathrm{~m}$ of Holocene sabkha-overprinted intertidal to shallow lagoonal sediments are well exposed (Kirkham, 1998). Prior to the construction of the canal the sabkha formed the modern land surface. Since then this surface was locally raised by up to a metre as gravel was dumped during reclamation of the area for industrial use. 

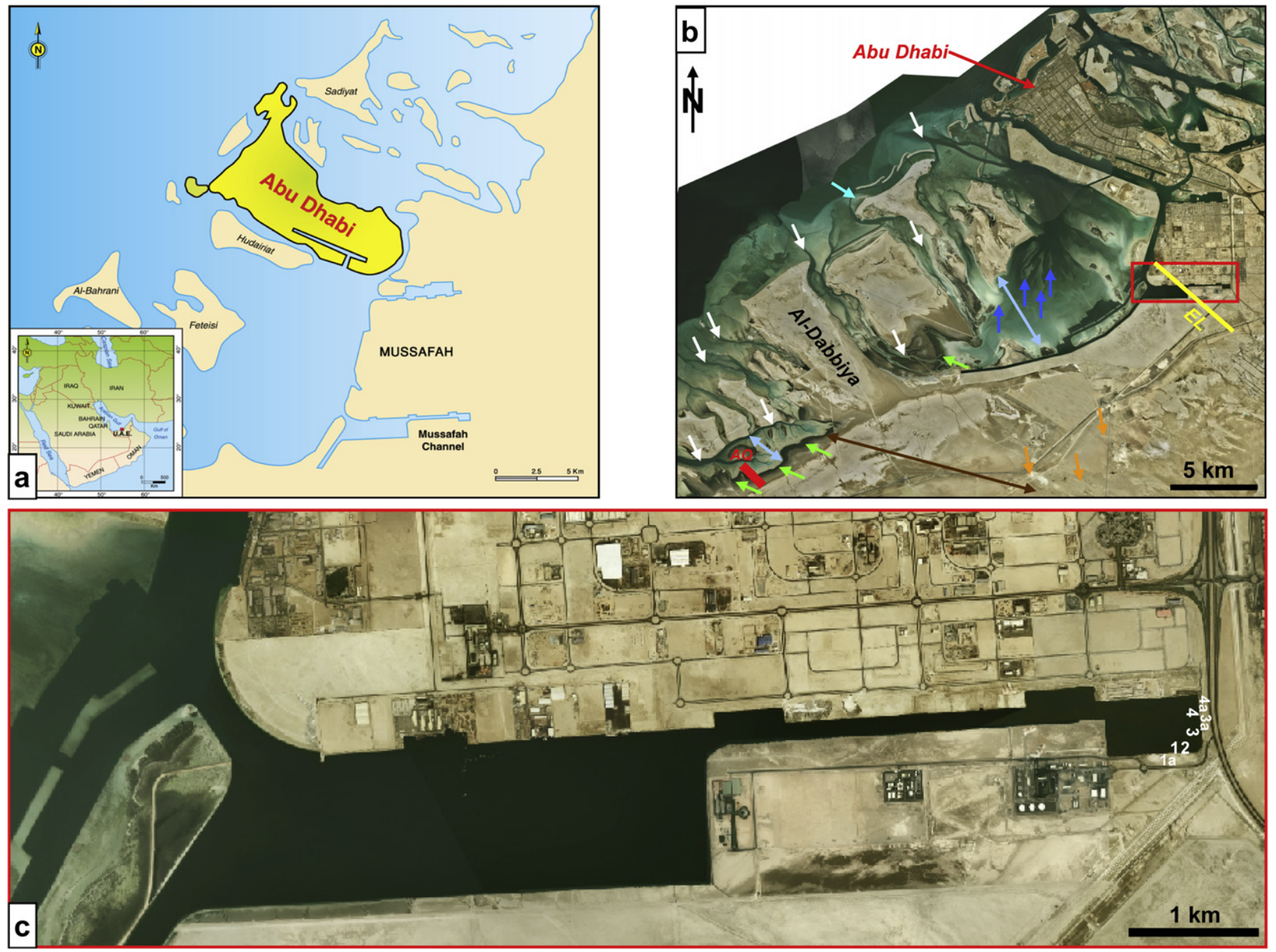

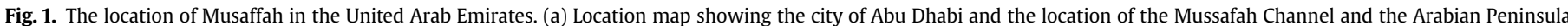

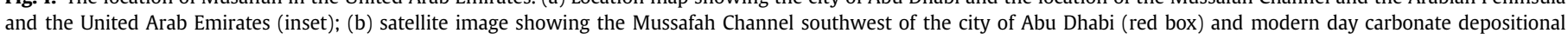

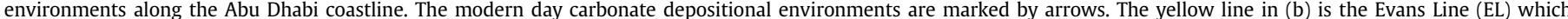

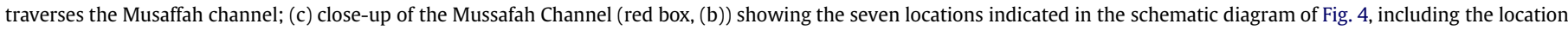

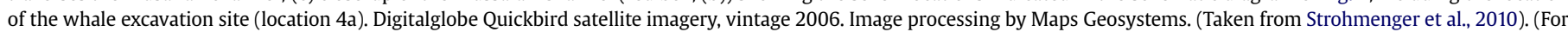
interpretation of the references to colour in this figure legend, the reader is referred to the web version of this article.)

This paper provides a description of the Musaffah cetacean bones which appear to represent associated parts of a single individual (Fig. 3). We also describe the depositional setting and age of this find and an attempt is made to explain the presence of the whale in the context of the overall sedimentary sequence. Finally, the opportunity was taken to undertake a detailed investigation of the palaeoecology of the sediments at Musaffah, this represents the first such study employing a combination of microfossils (foraminifera and ostracods) as well as molluscs from this important sequence.

\section{Regional context}

The Abu Dhabi sabkha, along the south-eastern coast of the Arabian Gulf has been studied by numerous geoscientist since the early 1960s (Wells, 1962; Curtis et al., 1963; Kendall and Skipwith, 1968, 1969; Butler, 1969, 1970; Evans et al., 1969; Kinsman, 1969; Purser, 1973; Park, 1977; McKenzie et al., 1980; McKenzie, 1981; Butler et al., 1982; Shearman, 1983; Shinn, 1983; Warren and Kendall, 1985; Kendall and Warren, 1988; Kenig et al., 1990; Kenig, 1991, 2011; Alsharhan and Kendall, 1994, 2002; Kendall et al., 1994, 2002; Evans, 1995; Peebles et al., 1995; Kirkham, 1997, 1998; Alsharhan et al., 1998; Sanford and Wood, 2001; Evans and Kirkham, 2002; Wood and Sanford, 2002; Wood et al., 2002, 2005; Strohmenger et al., 2004, 2008, 2010, 2011; Bontognali et al., 2008, 2010).

The Abu Dhabi coastline provides one of the few areas in the world to study the interplay between carbonate and evaporite sedimentation. The sequence at Musaffah provides a valuable section where sediments can be observed that illustrates the succession of carbonate and evaporite deposits. These include supratidal sabkha to uppermost intertidal microbial mat and lowermost intertidal to shallow subtidal lagoonal, tidal-channel, tidal delta, and longshore beach bar and beach spit environments (Strohmenger et al., 2004, 2010).

The Arabian Gulf coastline of Abu Dhabi is made up of a series of linear islands perpendicular to the coast that punctuate and border a large lagoonal complex (Fig. 1a and b). The large lagoon to the west of the region, the Khor Al Bazm, formed in a westerly plunging structural depression. To the north of this depression is an associated ridge, the Great Pearl Bank, which also plunges to the west and is orientated obliquely to the coast. This relief is related to 


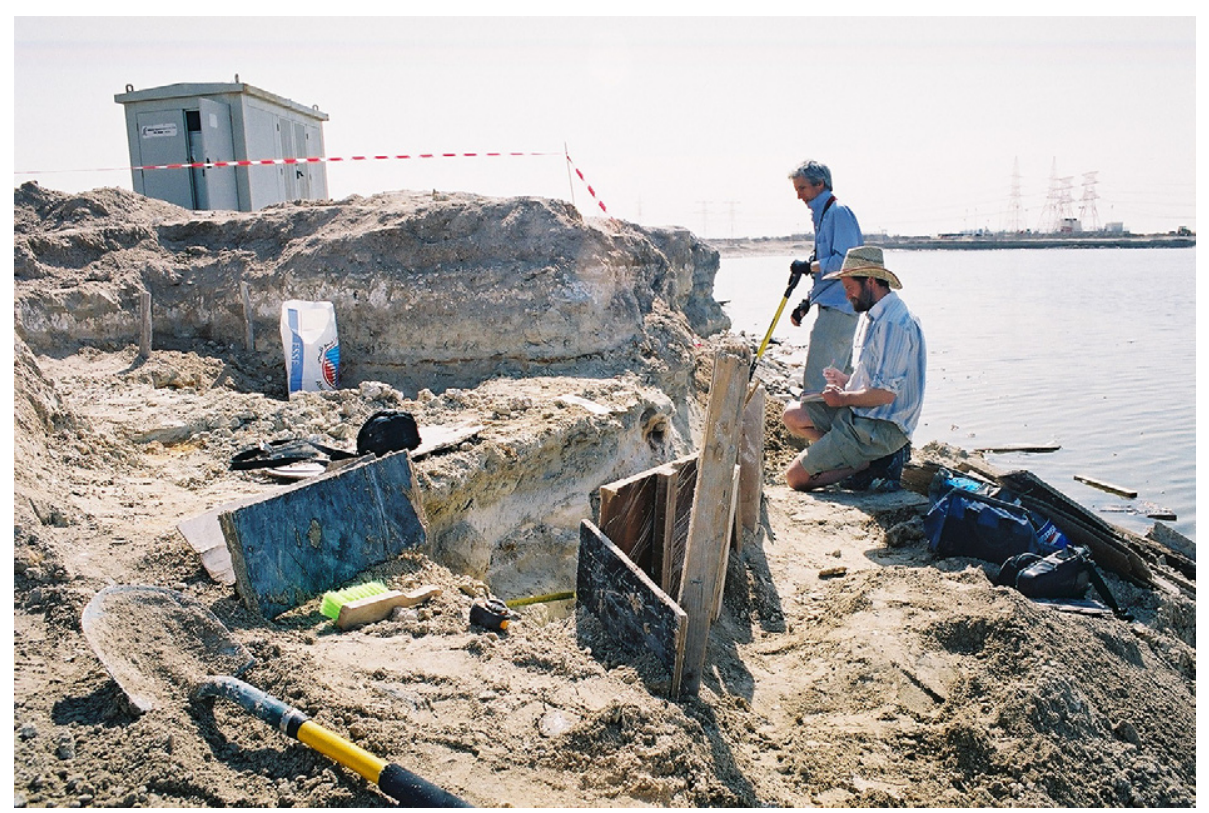

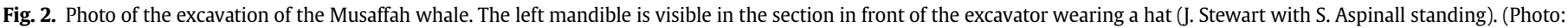
N. Larkin).

a deep-seated subsurface structural strike which has influenced sedimentation since the Pleistocene.

The recent coastline is the product of the Flandrian transgression which began ca 18,000 years before present (yrs BP) and reached its highest level during the Late Holocene, between ca 6000 (Kassler, 1973; Lambeck, 1996; Lambeck et al., 2002) and ca 4000 yrs BP (Evans et al., 1969, 2002; Evans and Kirkham, 2002), before the subsequent sea-level fall to its present level which had occurred by ca 1000 yrs BP. A formerly $1-2 \mathrm{~m}$ higher sea-level is confirmed by the presence of an eroded fossil beach-ridge system landward of and sub-parallel to the present-day coastline and the sediments exposed at Mussafah channel (Evans et al., 1969; Strohmenger et al., 2010).

The relative isolation of the Arabian Gulf from the open sea of the Indian Ocean results in higher salinities across the basin, varying from central surface averages of $37-40 \%$ in shallower parts near the coast to $60-70 \%$ in the remote lagoons in areas such as along the Abu Dhabi coastline (Purser and Seibold, 1973; Edwards et al., 1986). These salinities are matched by high temperatures increasing from the entrance of the Arabian Gulf, at the Strait of Hormuz, to their highest levels in the shallow bays and lagoons.

Today the Arabian Gulf region has an arid, subtropical climate with summer temperatures that exceed $50{ }^{\circ} \mathrm{C}$ with accompanying winds that promote evaporation and aeolian deposition. The almost landlocked nature of the Arabian Gulf makes the climate very continental in nature in terms of its seasonality, which contrasts with the relatively high levels of humidity (averaging $40 \%$ during the day and $90 \%$ during the night). These arid conditions began at around $6000 \mathrm{yrs}$ BP although dune formation may have halted at about 2000 yrs BP (Bray and Stokes, 2004). This gives a variable environmental backdrop to the carbonate deposition in the basin. In addition to this variability there are also seasonal Shamal winds that blow mainly from the northwest. It is these winds that contribute to the desert sand dune formations on the Arabian Peninsula as well as to the formation and dispersal of the carbonate sands along the south-eastern edge of the Arabian Gulf, along the UAE coast. This has produced the high-energy bioclastic and oolitic Holocene sediments that occur down to $20 \mathrm{~m}$ depth suggesting that the effective wave depth was relatively deep (Purser and Seibold, 1973). In the coastal tidal-channels, tidal velocities reach up to $60 \mathrm{~cm} / \mathrm{s}$ and produce bi-directional oolitic tidal deltas. During high tides that coincide with Shamal winds huge volumes of water can move inland for up to $3.5 \mathrm{~km}$, temporarily drowning the sabkha and coastal beach areas.

\section{Stratigraphic context}

The section along the man-made channel shows a sequence of gypsum- and anhydrite-overprinted intertidal to shallow subtidal carbonates (Figs. 4 and 5). The succession varies considerably laterally as well as vertically. From base to top the following lithofacies types can be observed (Strohmenger et al., 2010):

- cross-bedded to non-bedded carbonate-rich sand (aeolianite/ reworked aeolianite). Note that a presumed Pleistocene quartzose sand underlies the basal aeolian carbonate sand and is exposed at the eastern extremity of the Musaffah Channel (Kirkham, 1998);

- crinkly-laminated stromatolitic bindstone (intertidal, lowenergy microbial mat);

- lower, discontinuous and in places reworked hardground (cemented channel-lag deposits);

- peloid-skeletal packstone with rootlets or microbial-laminated peloid-skeletal packstone, laterally grading into fine- to coarsegrained, cross-bedded, cerithid-rich bioclastic packstone, grainstone, and rudstone (lowermost intertidal to shallow subtidal, low-energy, mud-rich rooted and microbiallaminated lagoonal deposits and moderate to high-energy, intertidal to shallow subtidal tidal-channel, tidal delta, and tidal-bar deposits);

- upper discontinuous and shingled hardground (cemented beach rock); and

- cross-bedded, bioclastic rudstone/grainstone, grading laterally into intervals displaying bladed gypsum crystals and nodular to enterolithic anhydrite (intertidal to shallow subtidal, highenergy longshore beach bar and beach spit deposits; overprinted by sabkha gypsum and anhydrite). 


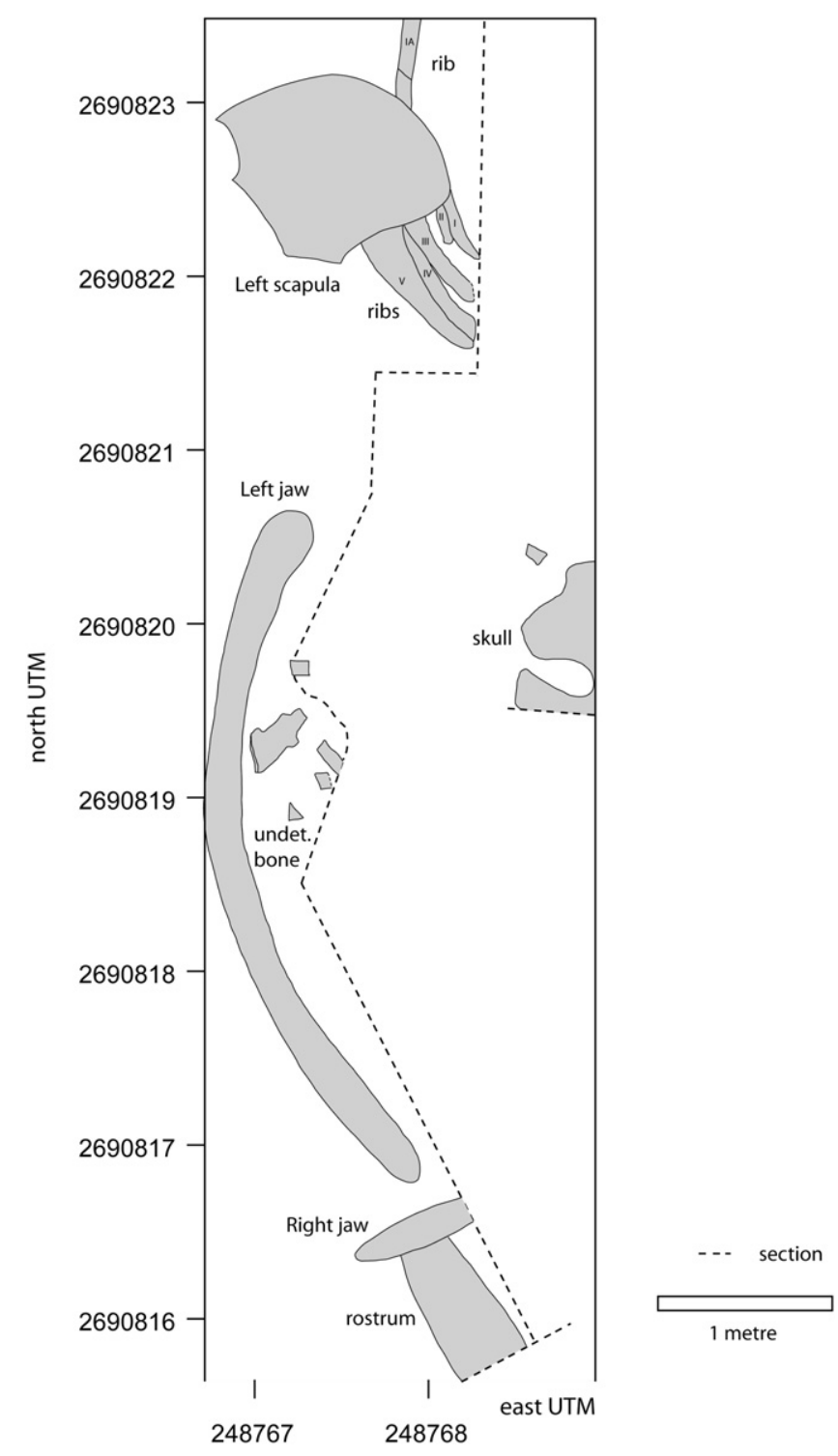

Fig. 3. Plan of cetacean bones excavated during January 2008 (Figure: R. Miller).

The whale remains were found at the northern end of the eastern wall of the Mussafah channel where ca $1.20 \mathrm{~m}$ of Holocene, sabkha-overprinted carbonates are well-exposed. These Holocene sediments overlie Pleistocene aeolian dune deposits (carbonaterich sand) with an un-calibrated radiocarbon age of ca $24,000{ }^{14} \mathrm{C}$ yrs BP. Overlying this Pleistocene carbonate-rich sand is a ca $10 \mathrm{~cm}$ thick microbial mat that can be traced along the entire channel walls. This microbial mat (intertidal deposit) marks the transgression of the Holocene sea and has an un-calibrated radiocarbon age of $6600-6200{ }^{14} \mathrm{C}$ yrs BP yrs. The microbial mat is followed vertically by cerithid-rich bioclastic grainstone (thickness: ca $15 \mathrm{~cm}$ ), fine-grained/coarse-grained bioclastic grainstone (thickness: ca $35 \mathrm{~cm}$ ), interpreted to correspond to tidal-channel deposits, and peloid-skeletal packstone/grainstone (thickness: ca $30 \mathrm{~cm}$ ) interpreted as shallow lagoon and tidal-channel deposits. The latter displays reddish horizontal horizons, interpreted as palaeo-water tables (Kirkham, 1998). The fine-grained/coarsegrained bioclastic grainstone have an un-calibrated radiocarbon age of ca $5200{ }^{14} \mathrm{C}$ yrs BP. A hardground is developed within the lower part of the cerithid-rich bioclastic grainstone and the upper part of the underlying microbial mat. Remains of the whale were found directly above the hardground within the certhid-rich bioclastic grainstone, the fine-grained/coarse-grained bioclastic grainstone, and the peloid-skeletal packstone/grainstone. Overlying the peloid-skeletal packstone/grainstone (shallow lagoon and tidal-channel deposits) are gypsum-overprinted, low-angle crossbedded to parallel-bedded, bioclastic rudstone/grainstone (thickness: ca $15 \mathrm{~cm}$ ) and anhydrite-overprinted, cross-bedded to parallel-bedded, bioclastic rudstone/grainstone (thickness: ca $15 \mathrm{~cm}$ ), interpreted as longshore beach bar and beach spit deposits (Strohmenger et al., 2010).

The Holocene vertical section represents a transgressive (deepening-upward) facies succession from intertidal (microbial mat) to shallow subtidal to intertidal (predominantly tidal-channel and minor lagoon, as well as gypsum- and anhydrite-overprinted longshore beach bar and beach spit) deposits, with a marine flooding surface on top of the Pleistocene carbonate-rich sands (reworked aeolian dune deposits). The slow rising/still stand and regressive phase of the sea-level is represented by the prograding longshore beach bar and beach spit deposits and the strong diagenetic (evaporitic) sabkha-overprint, resulting in the growth of gypsum and anhydrite (Strohmenger et al., 2010).

\section{Dating}

Radiocarbon dating was carried out on carbonate-rich sands and carbonates from 5 different vertical sections along the Musaffah channel wall (Strohmenger et al., 2010) (Table 1). The radiocarbon age-dating was carried out by Beta Analytic Inc., Miami. The results of 14 separate samples give un-calibrated, conventional ${ }^{14} \mathrm{C}$ ages for a variety of different facies along the channel wall. Dates varied between $26,760 \pm 180{ }^{14} \mathrm{C}$ yrs BP and $5150 \pm 60{ }^{14} \mathrm{C}$ yrs BP. The clusters of the four dates with values older than $20,000{ }^{14} \mathrm{C}$ yrs BP are all derived from the carbonate-rich sands (aeolianite or reworked aeolianite of terrestrial wind blown origin) that underlie the microbial mat. These un-calibrated dates put these sediments in the time frame of the Last Glacial Maximum. The next sediment in the generalised sequence is the microbial mat which across the five sections produced ages between $6590 \pm 40{ }^{14} \mathrm{C}$ yrs BP and $6140 \pm 50{ }^{14} \mathrm{C}$ yrs BP. The overlying lagoonal and tidal-channel deposits gave radiocarbon ages between $6160 \pm 50{ }^{14} \mathrm{C}$ yrs BP and $5150 \pm 60{ }^{14} \mathrm{C}$ yrs BP, and the uppermost longshore beach bar and beach spit deposits gave a radiocarbon age of $4950 \pm{ }^{14} \mathrm{C}$ yrs BP. At a measured vertical section close to the site where the whale bones were found, two radiocarbon ages were obtained from the microbial mat underlying the whale bones $\left(6590 \pm 40{ }^{14} \mathrm{C}\right.$ yrs BP $)$ and for the fine-grained/coarse-grained, bioclastic grainstone, encasing parts of the whale bones $\left(5150 \pm 60{ }^{14} \mathrm{C}\right.$ yrs BP). These two radiocarbon age-dates closely bracket the age of the whale and the time it took to bury the whale at the Mussafah Channel site.

\section{Palaeontology}

\subsection{The cetacean remains}

The excavation of the cetacean material here described took place between the 15th and 30th of January 2008 (Fig. 2). The excavation first involved the uncovering of the left scapula and left mandible, skeletal elements that were already known to be present (Fig. 3). This involved removing both natural overburden and humanly deposited material above it, and digging a trench around both bones to enable them to be exposed in their entirety so that they could be recorded in 3D and subsequently to allow conservation and lifting. During this time a test pit was dug inland of the edge of the man-made channel with the aim of finding the whale skull which eventually led to the uncovering of the left side of the 


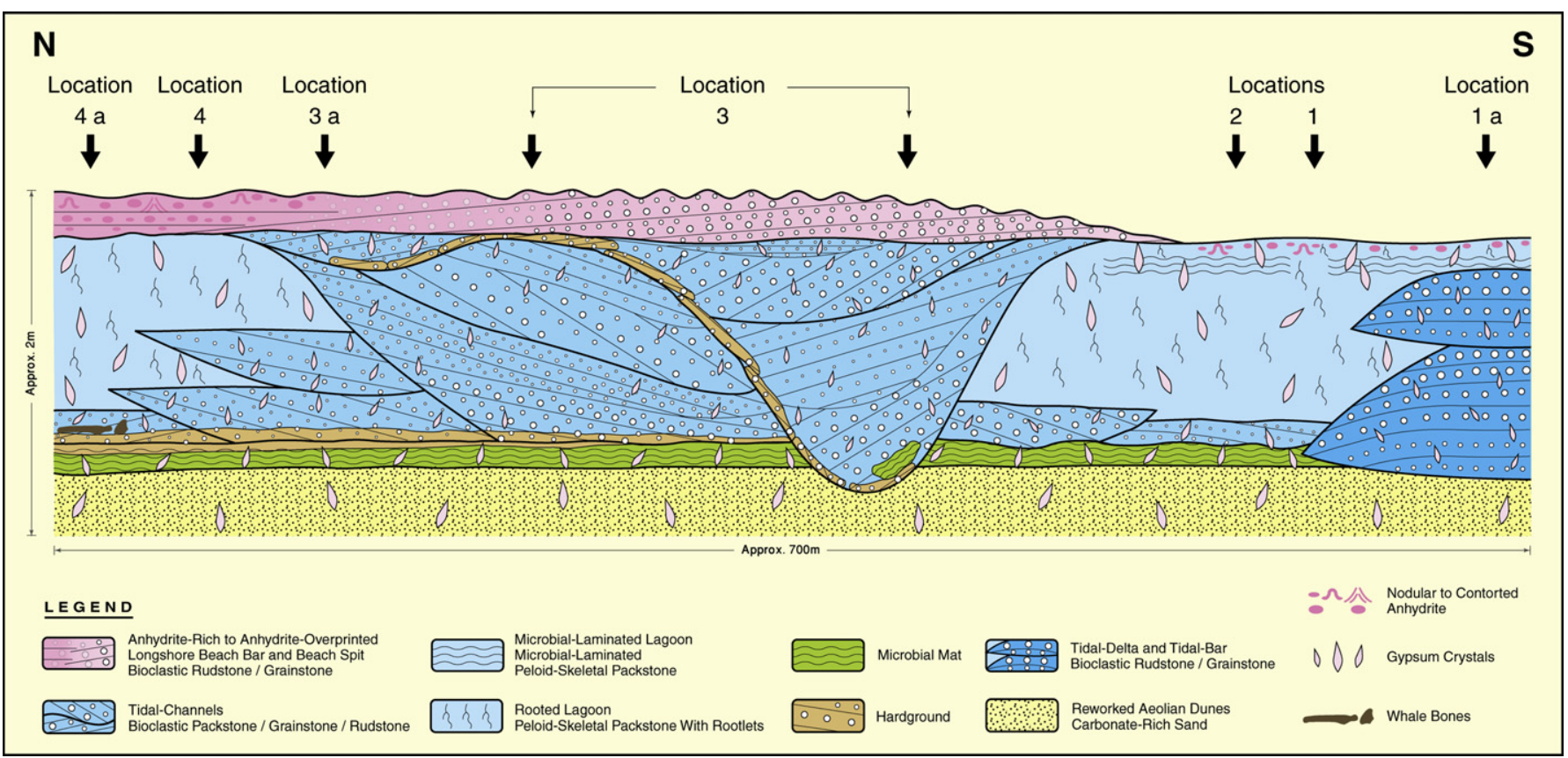

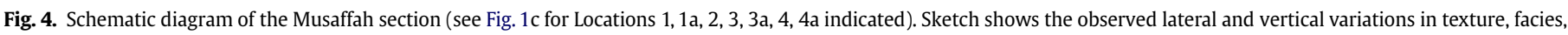

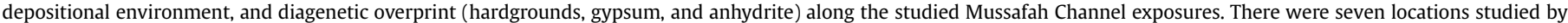
Strohmenger et al., 2010 including location 4a: site of whale bone exposure. (Taken from Strohmenger et al., 2010).

zygomatic arch of the cranium. The digging of the trench around the scapula revealed five ribs on the landward (eastern) side which were plunging underneath the scapula. The trench dug around the left mandible led to the discovery, to the south, of the tip of the right mandible and what appeared to be part of the whale's rostrum (Fig. 3). The right mandible was orientated perpendicular to the left one while the rostrum was in front of the left mandible and parallel with the edge of the north-south cutting. In addition, a number of as yet undetermined smaller bone fragments were discovered during the excavation of the trench east of the left mandible.

Although the bones uncovered (scapula, ribs, mandible and skull fragments) exhibited fine surface detail, they were all in a brittle state of preservation and occasionally cracked, with no great mechanical strength. The bones were not mineralised although they were coloured orange in places, presumably due to staining by iron oxide. The brittle state of the bones reflects the lack of organic preservation which would otherwise give the bones their elastic strength. Some bones were found broken in situ and some (such as the upper surfaces of the distal ends of the mandible and the upper surface of the skull) had apparently suffered from weathering prior to preservation, which is consistent with the brown colouration indicative of an oxidative environment. Large gypsum crystals, common throughout certain layers of the host sediment that formed near the bone often penetrated the bone, to a depth of up to 10 or $15 \mathrm{~mm}$.

The two bones recovered during the excavation were the left scapula and the left mandible. To do so the bones were first strengthened using a consolidant, a reversible methacrylate copolymer Paraloid B72 at 10\% in acetone. The consolidated bones and sediment were then covered with acid-free tissue paper and aluminium foil, followed by a thick covering of coarse hessian strips saturated with plaster of Paris to build up a thick protective jacket In addition the two objects were given further support by using wooden splints (the scapula) and a metal frame (the mandible) to which the jackets were attached with hessian and plaster. One problem, which may have a bearing on the depositional and postdepositional history of the bones, is the fact that the ascending ramus of the left mandible descended into the hard ground layer below and therefore required extracting using a hammer and chisel.

The five associated ribs, the distal end of the right mandible, which was protruding from the section, and the various skull elements were not lifted during the excavation. The exposed parts of these bones and the sediment immediately surrounding them were consolidated with Paraloid B72 in acetone at $10 \%$. They were then covered in protective plaster jackets which were covered with spoil.

In addition to the bones that were excavated in January 2008 a number of specimens had been previously removed in an unsystematic manner from the Musaffah site to storage. They were not left in situ because they were vulnerable to weathering or were likely to be damaged. These were the left humerus, radius and ulna. The humerus was mostly complete, but the radius and ulna required extensive repairs with reversible Paraloid B72 adhesive as they had been found in pieces in spoil at the foot of the section before the excavation.

The whale remains found at Musaffah, including a left scapula, a near complete left mandible, the tip of a right mandible, a partial rostrum, a partial cranium, five ribs, a left humerus, a fragmentary left radius and a fragmentary left ulna, would appear to represent a single individual which are partly disarticulated although certainly associated (Figs. 3 and 6). Because the remains of the whale have only been partly excavated, only notable features that might aid in its identification are described here. The rostrum and the left posterolateral corner of the cranium have only partly been exposed, precluding the assessment of most cranial features. However, it is clear that the lateral edge of the rostrum is dorsoventrally thin, and that the zygomatic processes of the squamosal are directed anterolaterally. The dentaries are not fused anteriorly and instead show an anteroposterior groove near the anterior end indicating a ligamentous symphysis. The left mandible is four 


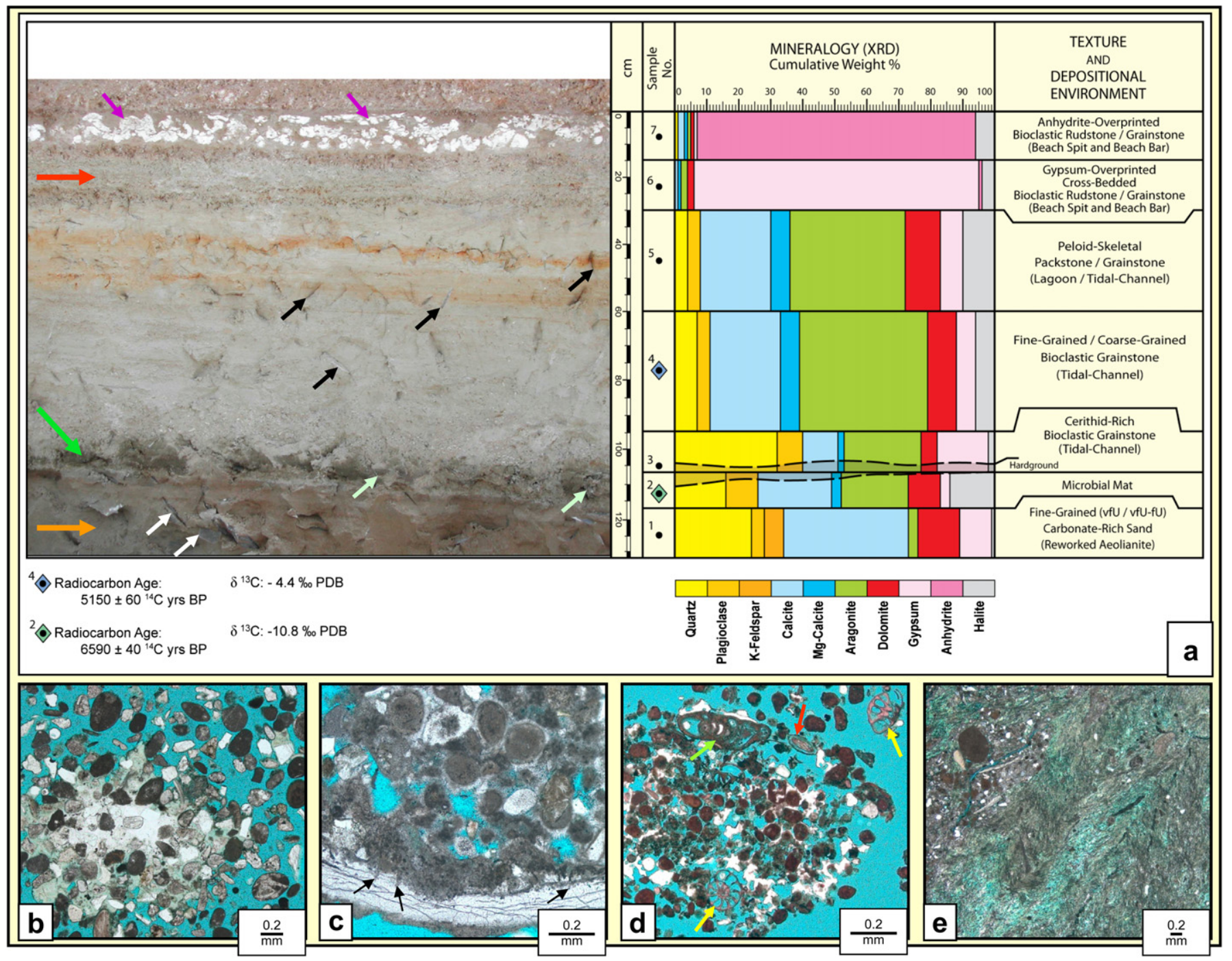

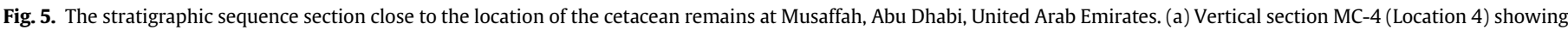

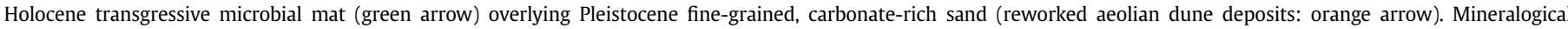

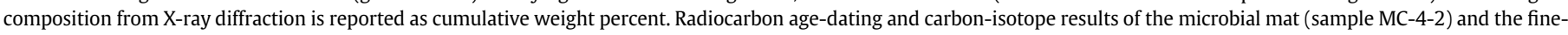

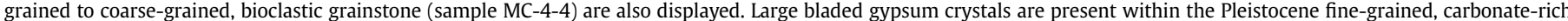

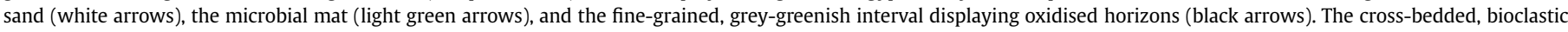

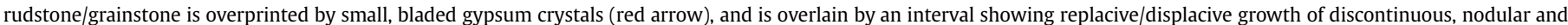

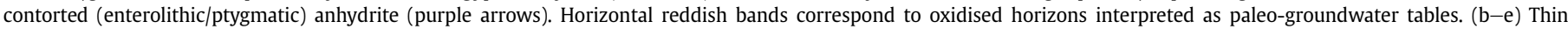

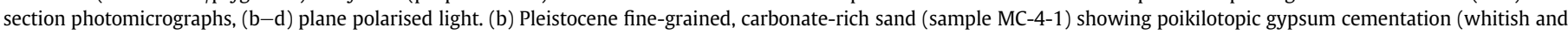

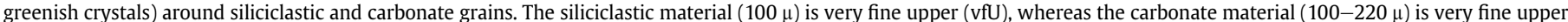

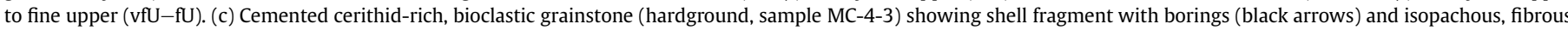

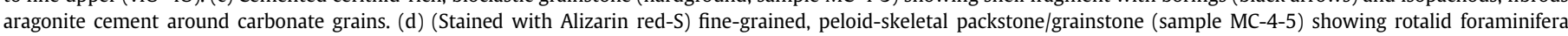

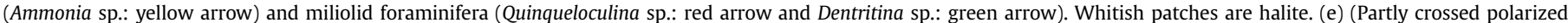

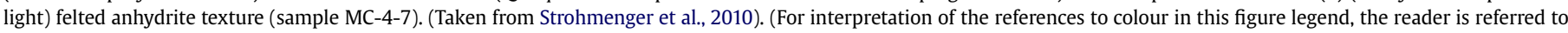
the web version of this article.)

metres in length as measured along the arc, bears no teeth, is strongly bowed outwards and has an overall sigmoidal outline in ventral view. It bears a condyle with a posteriorly directed articular surface and a subcondylar furrow that is well defined on the external side of the dentary, clearly separating the angular process ventrally from the condyle above. The most distinctive features of the postcranial bones include a reduced coracoid process and the absence of an acromion on the scapula, as well as a markedly reduced olecranon of the ulna.

The absence of teeth, the unfused mandibular symphysis and the thin lateral edge of the rostrum unequivocally place this specimen in the Mysticeti (baleen whales), which are represented by four extant families: Balaenopteridae (rorquals), Balaenidae (right whales), Eschrichtiidae (grey whale) and Neobalaenidae (pygmy right whale) (Deméré et al., 2005; Mead and Brownell, 2005). The sigmoidal outline of the mandible, the posteriorly directed articular surface of the condyle and the presence of a subcondylar furrow on the external side are typical of balaenopterids and clearly distinguish them from all other extant mysticete families (Deméré, 1986; Steeman, 2007). The family Balaenopteridae comprises two extant genera: the monospecific Megaptera (humpback whale) and Balaenoptera (all other rorquals, such as minke, fin and blue whales) (Mead and Brownell, 2005). In members of the genus Balaenoptera, the acromion and coracoid processes of the scapula are typically 
Table 1

Radiocarbon dates from Musaffah. Locations of the sections are on Fig. 1.

\begin{tabular}{|c|c|c|c|c|c|}
\hline Section & Deposit & Radiocarbon ages & $\delta{ }^{13} \mathrm{C}(\%)$ & Lab \# & Calibrated dates \\
\hline \multirow[t]{2}{*}{ Section 1} & Microbial mat & $6600( \pm 40)$ years BP & -10.6 & Beta-237864 & cal BC 5154-4782 \\
\hline & Reworked aeolianite & $23,530( \pm 140)$ years & +0.7 & Beta-226038 & cal BC 26210-25436 \\
\hline \multirow[t]{3}{*}{ Section 2} & Microbial mat & $6180( \pm 50)$ years BP & -10.1 & Beta-226044 & cal BC 4646-4323 \\
\hline & Reworked aeolianite & $23,490( \pm 130)$ years & +0.1 & Beta-226043 & cal BC 26136-25438 \\
\hline & Aeolianite & $26,760( \pm 180)$ years & -0.1 & Beta-226042 & cal BC 29222-28571 \\
\hline \multirow[t]{4}{*}{ Section 3} & Hardground & $5660( \pm 70)$ years & -3.2 & Beta-226049 & cal BC 4134-3696 \\
\hline & Tidal-channel & $6160( \pm 50)$ years & +0.1 & Beta-237865 & cal BC 4630-4308 \\
\hline & Microbial mat & $6140( \pm 50)$ years & -9.9 & Beta-226047 & cal BC 4602-4281 \\
\hline & Reworked aeolianite & $24,010( \pm 150)$ years & +0.7 & Beta-226046 & cal BC 26596-25866 \\
\hline \multirow[t]{3}{*}{ Section 4} & Beach bar / Beach spit & $4950( \pm 60)$ years & -12.2 & Beta-226052 & cal BC 3313-2892 \\
\hline & Tidal-channel & $5190( \pm 50)$ years & +0.2 & Beta-237866 & cal BC 3617-3244 \\
\hline & Hardground & $6400( \pm 70)$ years & -2.5 & Beta-226050 & cal BC 4931-4499 \\
\hline \multirow[t]{2}{*}{ Section 5} & Tidal-channel & $5150( \pm 60)$ years & -4.4 & Beta-239058 & cal BC 3564-3098 \\
\hline & Microbial mat & $6590( \pm 40)$ years & -10.8 & Beta-237867 & cal BC 5141-4769 \\
\hline
\end{tabular}

Notes: all dates are calibrated using CALIB (Stuiver et al., 2005) to 2 sigma assuming a marine source for the sample.

well developed, and the olecranon of the ulna is present as a distinct and proximodistally elongate process (e.g. Andrews, 1916; Omura, 1959, 1975; Omura et al., 1970). By contrast, all of these features are reduced or absent in Megaptera (Struthers, 1888; Deméré et al., 2005), which, in addition, can be further distinguished from Balaenoptera by relatively more laterally directed zygomatic processes of the squamosal (Nagasawa and Mitani, 2004; Deméré et al., 2005). Based on these features, we here tentatively assign the cetacean remains to the genus Megaptera, and thus its only constituent extant species, Megaptera cf. novaeangliae. The only other currently accepted taxon in this genus is the Late Miocene Megaptera affinis (Deméré et al., 2005). However, a full systematic description will have to await the confirmation of this identification following the complete excavation of the remains. It will be interesting to confirm the identity of the remains as humpback whale because there is a localised relatively sedentary population in the Arabian Sea (Mikhalev, 1997).

This identification is consistent with recent records of whales from the Arabian Gulf waters of the UAE because humpbacks are amongst the six baleen whales to have been reported live off the UAE east coast (data courtesy of the UAE National Cetacean Database, Environment agency - Abu Dhabi). The others are Bryde's whales (Balaenoptera edeni), blue whales (Balaenoptera musculus), which are deemed to be Pygmy Blue Whales in this region (Omura et al., 1970; Baldwin et al., 1999), fin whales (Balaenoptera physalus), minke whales (Balaenoptera acutorostrata) and sei whales (Balaenoptera borealis). However, there are only 32 records of whales, larger than killer whales (Orcinus orca), from the Arabian Gulf

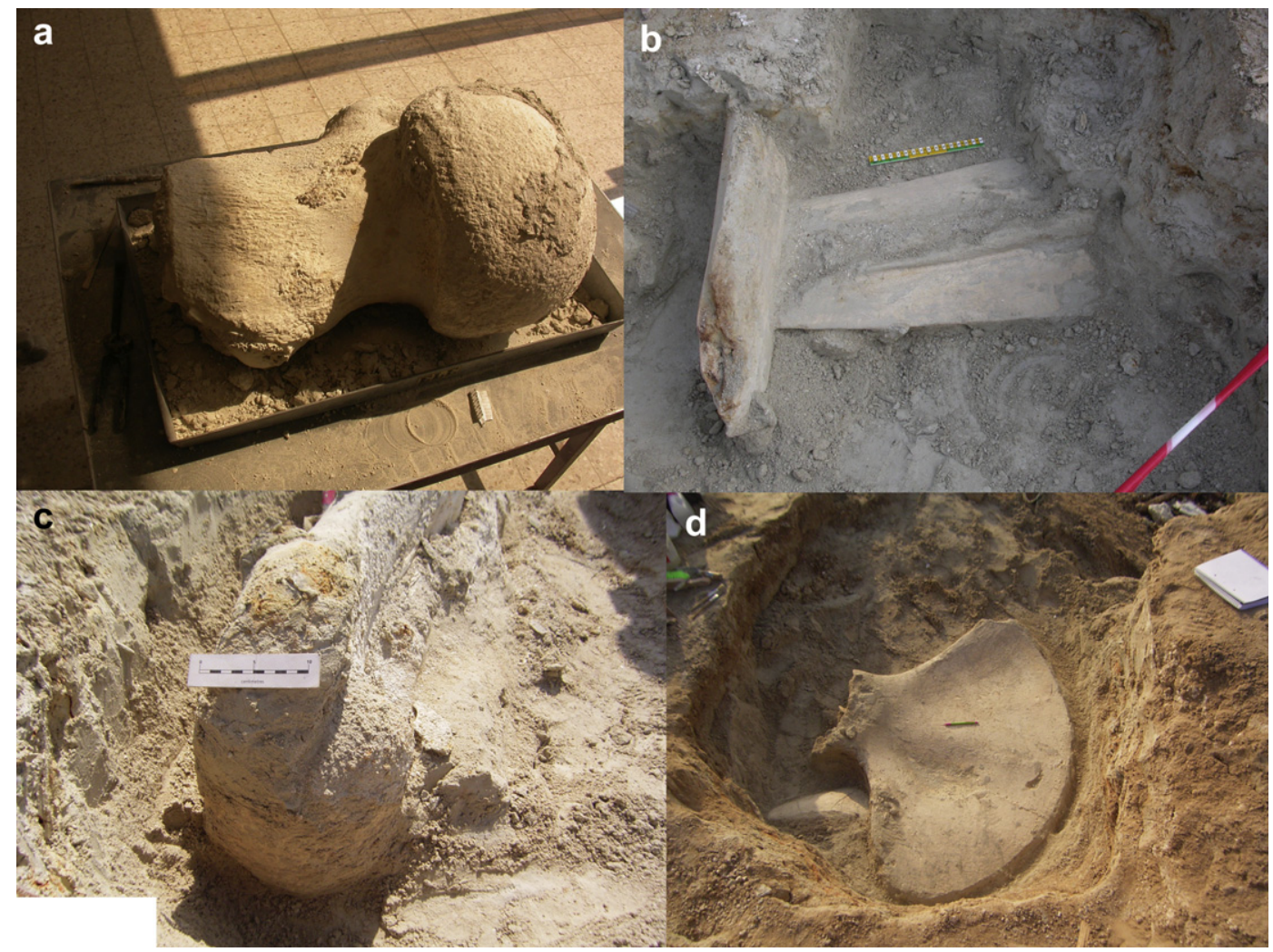

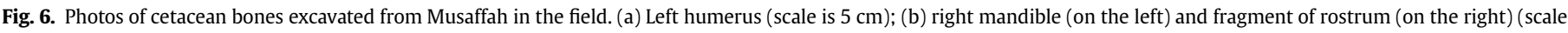
is $30 \mathrm{~cm}$ ); (c) articulation of left mandible (scale is $10 \mathrm{~cm}$ ) and (d) left scapula (pencil is approximately $15 \mathrm{~cm})$. (Photos: N. Larkin and J. Stewart). 
Table 2

List of aDNA samples and their locations from Musaffah.

\begin{tabular}{lll}
\hline Sample ID & Description & $\begin{array}{l}\text { Amount of material } \\
\text { used for DNA extraction (mg) }\end{array}$ \\
\hline SP2270 & $\begin{array}{l}\text { MUS17, Mussafata, } \\
\text { Abu Dhabi, 24-01-2008, cetacean }\end{array}$ & 270 \\
SP2271 & $\begin{array}{l}\text { MUS, Musaffah, Abu Dhabi, } \\
\text { fragment of rib, cetacean }\end{array}$ & 200 \\
\hline
\end{tabular}

waters of the UAE, of which a minimum of 22 individuals are considered to have been baleen whales. Few of the records in the UAE national database represent recently beached individuals, all invariably having arrived already long dead, and only occasionally have floating cadavers yet to beach been reported (3 recent records). Recent years have seen no strandings of large whales along the UAE's east coast, and even those of the smaller toothed whales and dolphins are exceedingly rare here.

All the bones of the Musaffah whale appear to be upside down, which may indicate that the whale was dead when it arrived in the lagoonal environment in whose sediments it is now buried. This is a very different scenario to that represented by many other cetacean remains. In the past finds have more often been found in deeper water deposits such as those from the Neogene crags of the Antwerp basin in Belgium, which included articulated or associated material (e.g. van Beneden, 1872; Bosselaers et al., 2004), as well as other Neogene finds from Spain (Esparante et al., 2009), Britain (Lydekker, 1887), Romania (Kazar and Venczel, 2003) as well as older ones from Egypt and Pakistan (Fordyce and Barnes, 1994). In addition finds of cetaceans have also been made from archaeological sites dated from the prehistoric to medieval times (Gardiner et al., 1999; Mulville, 2002). The example described by Gardiner et al. (1999) are remains of northern right whale from a natural beach accumulation in England although marks indicative of human action can be observed on various skeletal elements. No evidence of butchery was found on the Musaffah whale so there is no indication that they attracted the attention of the local population. This is interesting as there were humans living in the region during the mid-Holocene that were exploiting marine mammals like dugongs, and sometimes in large quantities (Beech, 2010).

\subsection{Ancient DNA analysis}

Two samples of bone from the Musaffah whale were sent for analysis to Planck Institute for Evolutionary Anthropology, Leipzig. The first (MUS17) was a fragment of an undetermined bone which appeared particularly well preserved from the sediments near the skull and the second was a fragment of rib from underneath the left scapula (Table 2). Alongside with other samples and mock controls, DNA was isolated from the two samples in a clean laboratory dedicated exclusively for ancient DNA (aDNA) work. We used an ancient DNA extraction technique described earlier (Rohland et al., 2010). Samples were tested for DNA preservation in PCR reactions with two different primer pairs, which were specifically designed to amplify parts of the mitochondrial D-loop of grey whales and most other cetaceans (Table 3 ). Briefly, $4 \mu$ l extract were used as template in PCR reactions containing $1 \mathrm{U}$ AmpliTaq Gold DNA polymerase (Applied Biosystems) and in final concentrations $1 \times$ PCR buffer II, $4 \mathrm{mM} \mathrm{MgCl}_{2}, 1.6 \mu \mathrm{g} / \mu \mathrm{l} \mathrm{BSA}$ and $200 \mathrm{nM}$ each primer. Cycling conditions were composed of an activation step lasting $10 \mathrm{~min}$ at $95^{\circ} \mathrm{C}$, followed by 60 cycles of denaturation at $95^{\circ} \mathrm{C}$ for $30 \mathrm{~s}$, annealing at $51^{\circ} \mathrm{C}$ for $30 \mathrm{~s}$ and elongation at $72{ }^{\circ} \mathrm{C}$ for $30 \mathrm{~s}$, with a final extension step at $72{ }^{\circ} \mathrm{C}$ for $10 \mathrm{~min}$. PCR was performed in replicates for each sample and primer pair. Following amplification, the products were separated on a $2 \%$ agarose gel and visualised by ethidium bromide staining. Visible bands were obtained only from amplification reactions using the primer pair W56/W16. However, the product sizes were greatly different from the expected amplicon size, indicating that environmental contamination, for example bacterial DNA, rather than endogenous DNA was amplified in these reactions. Thus, we did not attempt to sequence these products. Other ancient samples, which were in parallel carried through DNA extraction and amplification, yielded positive results, indicating that our attempt to amplify DNA from the two specimens indeed failed due to insufficient DNA preservation.

\subsection{Mollusca}

Two types of samples were analysed for mollusc remains around the whale skeleton. First, 4 large bulk samples (ca $20 \mathrm{~kg}$ ) were taken specifically for molluscan analysis. In addition, 10 smaller samples (ca $500 \mathrm{~g}$ ) were taken for micropalaeontological analysis (Table 4). Fig. 7 shows examples of some of the more common taxa identified.

The 4 bulk samples were taken from 2 locations across the area. These included 2 samples from the sediments banked up against the exposed portion of the skull including the coarse shelly sand band (MUS 9) at the base of a section next to the skull and the orange, iron-stained shelly sand (MUS 11) at the top. Second was a pair of bulk samples from around the whale scapula (MUS 1 and 2 ). These samples were sieved to 500 microns and the resultant residues dried in advance of sorting. Due to the super abundance of individuals and the species diversity being comparatively low systematic quantification was not attempted. Table 5 gives the results of the identification of mollusc taxa from the bulk samples with an approximate indication of their relative abundance.

The results of this analysis are as follows. The coarse-grained shelly sediment units such as those from bulk samples MUS 1, 2 and 9 are dominated by the gastropod Cerithideopsilla conica and the bivalve Dosinia ceylonica which are a surface algal feeder and a shallow sediment burrowing species, respectively. Both taxa are represented by a range of sizes including juveniles implying that their breeding area lay close by. The Dosinia are, however, represented by small individuals which may reflect a stressed environment perhaps from elevated salinity. It is just possible that MUS 1 differs from MUS 2 and 9 because it's low gastropod species diversity. Alternatively, because it came from a slightly different location next to the scapula, it may have differed because of sediment sorting, organising molluscs according to shape. The last bulk sample is MUS 11, from the iron-rich shelly deposit near the skull, whose assemblage included the bivalve Barbatia setigera and the

Table 3

aDNA analysis results.

\begin{tabular}{|c|c|c|c|}
\hline $\begin{array}{l}\text { Forward/reverse } \\
\text { primer IDs }\end{array}$ & Forward primer sequence $\left(5^{\prime}-3^{\prime}\right)$ & Reverse primer sequence $\left(5^{\prime}-3^{\prime}\right)$ & $\begin{array}{l}\text { Expected amplicon size } \\
\text { (including primers) (bp) }\end{array}$ \\
\hline W57/W58 & ACWTAAACTATTCCCTGAAA & AATACKGACATARYACTGTG & 67 \\
\hline W56/W16 & TATGTATAATYGTGCATTCA & CTGGTTTCACGCGGCAT & 206 \\
\hline
\end{tabular}


Table 4

Samples taken from sediments around whale skeleton at Musaffah, Abu Dhabi for mollusc and microfossil analyses.

\begin{tabular}{|c|c|c|c|c|}
\hline Sample \# & $\begin{array}{l}\text { Bulk vs Micropalaeontology } \\
\text { sample }\end{array}$ & $\begin{array}{l}\text { Sequence vs. } \\
\text { isolated sample }\end{array}$ & Locality & Sediment description \\
\hline MUS 1 & Bulk & Isolated & Surface and surroundings of the left scapula & Shelly sand \\
\hline MUS 2 & Bulk & Sequence 1 & Around the glenoid of the left scapula & Shelly sand (Same as MUS 3) \\
\hline MUS 3 & Micropal & Sequence 1 & Around glenoid of scapula of whale. & Shelly sand (Same as MUS 2) \\
\hline MUS 4 & Micropal & Sequence 1 & By glenoid of scapula of whale (below MUS 3) & Shelly sand (Less shelly than MUS 3 above) \\
\hline MUS 5 & Micropal & Sequence 2 & By whale skull. & Laminated sediment \\
\hline MUS 6 & Micropal & Sequence 2 & By whale skull (below MUS 5). & Top shell band \\
\hline MUS 7 & Micropal & Sequence 2 & By whale skull (below MUS 6). & Fine sediment \\
\hline MUS 8 & Micropal & Sequence 2 & By whale skull (below MUS 7). & Main shell band (Same as MUS 9) \\
\hline MUS 9 & Bulk & Sequence 2 & By whale skull (below MUS 7). & Main shell band (Same as MUS 8) \\
\hline MUS 10 & Micropal & Sequence 2 & By whale skull (above MUS 5). & Iron pan shelly band (Same as MUS 11) \\
\hline MUS 11 & Bulk & Sequence 2 & By whale skull (above MUS 5). & Iron pan shelly band (Same as MUS 10 ) \\
\hline MUS 14 & Micropal & Sequence 3 & Base of site. & Pleistocene sand? \\
\hline MUS 15 & Micropal & Sequence 3 & Above MUS 14. & Algal layer \\
\hline MUS 16 & Micropal & Sequence 3 & Above MUS 15. & Cemented layer \\
\hline MUS 27 & Micropal & Isolated & By articulation of "Jaw 1" & “Rootlet” horizon \\
\hline
\end{tabular}

gastropods Osilinus kotschyi and Serpuloides sp, all of which require a solid substrate to attach to. It may be that this slightly different species composition reflects the presence of the whale bones which could provide a localised stable substrate. Alternatively the ironrich sediment, which is slightly more cemented, may have been laid down in shallower water, making it sufficiently endurated to provide a substrate to which those molluscs could attach and thrive.

Other species found in the samples include the bivalve Brachidontes variabilis (in all 4 samples) which is an epifaunal species attaching to hard substrates by byssus threads, Carditopsis majeeda (3 out of 4, not in MUS 11), a shallow burrowing taxon, Fulvia fragile (1 out of 4 , only in MUS11), a burrower preferring soft muddy sands, and Tellina arsinoensis (in all 4 samples), a burrowing deposit feeder. The gastropods include Cerithium scabridum (in MUS 2 and 9), a surface browser, Obtortio pupoides (in MUS 2 and 9), a tiny browser found on algae, Mitrella blanda (MUS 2 and 9), whose habits are poorly known but is probably a generalist browser, Odostomia sp. (in MUS 2 and 9), a genus known to be parasitic on bivalves and polychaetes, and finally Retusa tarutana (3 out of 4, not in MUS 11), which forages on the sediment surface and other species of the genus are known to eat forams and tiny molluscs (Malaquias et al., 2009).

Molluscs were also sorted from the micropalaeontology samples taken and the species composition of these is shown in Table 6 . These samples are comparatively small and so should be interpreted with caution. However, samples MUS 3, 8 and 10 are smaller duplicates of the bulk samples MUS 2, 9 and 11 respectively. This allows a consideration of the reliability of these smaller samples through the taxa recovered in them compared to what was found in the bulk samples. Generally, they compare well although a few differences exist with taxa turning up in the small sample of the iron-stained horizon which were not in the bulk sample (see Tables 5 and 6). This may be due to chance as the numbers of individual molluscs recovered from sample 11 was less than in the other 3 bulk samples.

The most important contribution of the smaller samples was, however, that they covered a wider range of sediments and localities (Table 4), including additional and mostly smaller units in the sequence adjacent to the scapula (MUS 4) and the skull (MUS 5, 6 and 7). Sample MUS 4 is from a less shelly unit below the accumulation of shelly sand next to the glenoid fossa of the left scapula. MUS 5, 6 and 7 together with MUS 8 and 10, were from the sequence next to the skull. This sequence consisted of, from the base upwards, a main shelly sand unit (MUS 8) below a finer sediment (MUS 7), followed by the top shell band (MUS 6) and a laminated sediment (MUS 5) and then an iron-stained shelly sand unit (MUS 10), towards the top of the portion of skull. In addition, small samples were taken from the sands at the base of the sequence (MUS 14), these are thought to be dated to the Late Pleistocene, and the first marine sediments immediately above (MUS 15), which were immediately below the hard ground layer (Fig. 5). A lump of the cemented layer (MUS 16) was also taken but not analysed. Finally, a sample was taken from a sediment adjacent to the left mandibular condyle which showed apparent 'rootlet' marks (MUS 27).

The mollusc species in the samples are generally very similar to each other with any differences in composition being probably due to sediment sorting. For example, the less shelly unit near the left glenoid fossa of the scapula (MUS 4) and the more shelly sand below (MUS 2 and 3 ) have the same species composition as each other, differing only in lower numbers of individuals for each taxon (Table 6). The differences between the samples taken from the sequence next to the skull are also explained by differences in sediment particle size and hence sorting. The iron-stained horizon with a single specimen of Barbatia can be confirmed as the most different in the sequence indicating a local presence of a hard substrate. The final pair of samples coming from a sequence, at the base of the site, includes the Pleistocene sand (MUS 14) and the first marine sand (MUS 15) above it. The former (MUS 14) has small numbers of the most common species at the site which are likely to be contaminants as the sand has been interpreted as terrestrial dune sand. The latter (MUS 15), however, has a relatively rich and typical mollusc fauna for Musaffah albeit with 2 gastropods not found in other samples (micro or bulk samples). These are the species Tricolia fordiana and an undetermined juvenile member of the Trochidae. These indicate shallow water and $T$. fordiana is usually associated with sea grasses. The other new taxon recovered from a micro sample is the gastropod Phasianella solida which also has a shallow-water sea grass association and is recorded from MUS 8 which is the main shell band in the sequence next to the skull.

The interpretation of the molluscs from the micropalaeontological samples is generally the same as that of the bulk samples with indications in most samples of shallow water from surface substrate algal feeding gastropods (Cerithideopsilla, Cerithium, Obtortio, and possibly Mitrella and Retusa) as well as shallow burrowing bivalves (Carditopsis, Dosinia, Fulvia, Tellina). Additional environmental indications, in relatively small numbers, are the taxa associated with hard substrates (Barbatia, Osilinus and Serpulorbis) 


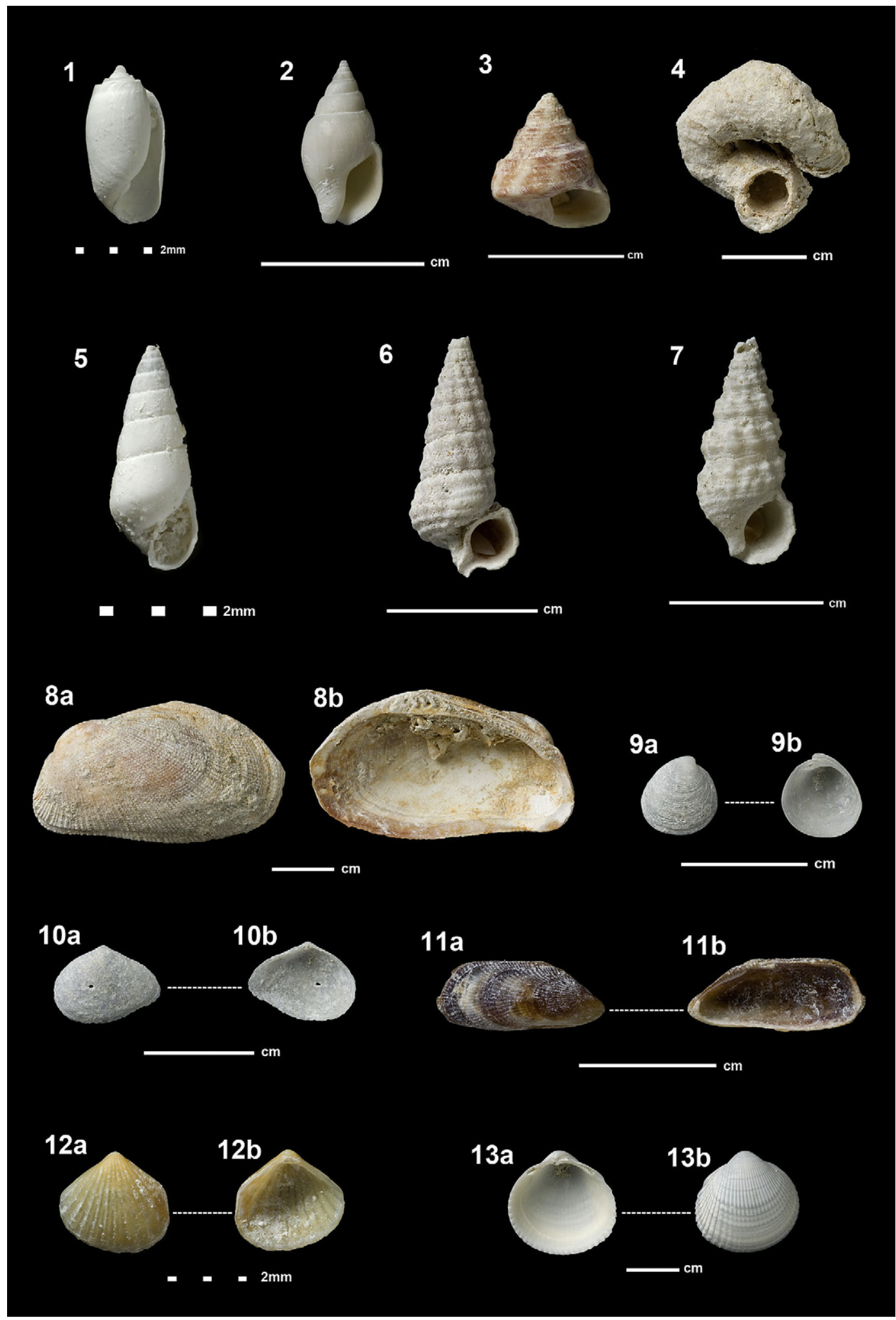

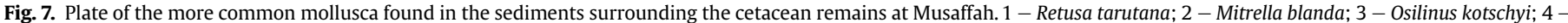

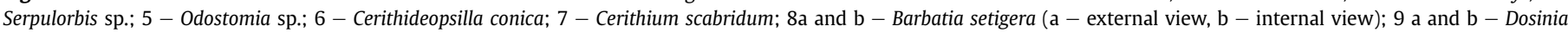

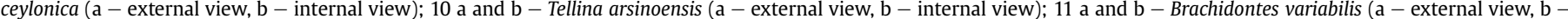

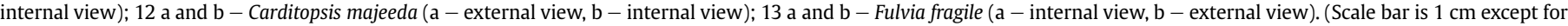
those for mollusc 1, 5 and 12 where it is $2 \mathrm{~mm}$ ) (Photos: NHM Photo Unit). 
Table 5

Mollusca from bulk samples taken during excavation of whale remains at Musaffah.

\begin{tabular}{lllll}
\hline & MUS 1 & MUS 2 & MUS 9 & MUS 11 \\
\hline Bivalves & & & & \\
Barbatia setigera (Reeve, 1844) & - & - & - & $4 \mathrm{v}$ \\
Brachidontes variabilis (Krauss, 1848) & $4 \mathrm{v}$ & $16 \mathrm{v}$ & $10 \mathrm{v}$ & $3 \mathrm{v}$ \\
Carditopsis majeeda (Biggs, 1973) & $5 \mathrm{v}$ & $5 \mathrm{v}$ & $5 \mathrm{v}$ & - \\
Fulvia fragile (Forskal, 1775) & $1 \mathrm{v}$ & - & - & - \\
Tellina arsinoensis (Issel, 1869) & $2 \mathrm{v}$ & $9 \mathrm{v}$ & $36 \mathrm{v}$ & $3 \mathrm{v}$ \\
Dosinia ceylonica (Dunker, 1865) & many & $83 \mathrm{v}$ & $100 \mathrm{~s}$ & $13 \mathrm{v}$ \\
Gastropods & & & & \\
Osilinus kotschyi (Philippi, 1849) & - & - & - & 3 \\
Cerithideopsilla conica (Blainville, 1826) & $10+$ & $100+$ & $100 \mathrm{~s}$ & 20 \\
Cerithium scabridum (Philippi, 1848) & - & 3 & 1 & - \\
Obtortio pupoides (A. Adams, 1860) & - & 4 & 20 & - \\
Serpulorbis sp. & - & - & - & 1 \\
Mitrella blanda (Sowerby, 1844) & - & 21 & 6 & - \\
Odostomia sp. & - & 1 & 2 & - \\
Retusa tarutana (Smythe, 1979) & 2 & 7 & 39 & - \\
\hline
\end{tabular}

Key: $v$ = valves.

from the iron-stained horizon next to the skull (MUS 10 and 11) and to a lesser extent from the shelly sand next to the left scapula (MUS 3 ) and the rootlet horizon next to the mandible articulation (MUS 27), both having Osilinus. Furthermore, sea grass associated taxa are present in the lower most marine deposit at Musaffah (Tricolia in MUS 15) and the main shell band next to the skull (Phasianella in MUS 8). Brachidontes, which is also often associated with hard

Table 6

Mollusca from samples taken for micropalaeontology during excavation of whale remains at Musaffah.

\begin{tabular}{|c|c|c|c|c|c|c|c|c|c|c|}
\hline \multirow[t]{2}{*}{ Taxon } & \multicolumn{10}{|c|}{ MUS Sample \# } \\
\hline & 3 & 4 & 5 & 6 & 7 & 8 & 10 & 14 & 15 & 27 \\
\hline \multicolumn{11}{|l|}{ Bivalves } \\
\hline $\begin{array}{r}\text { Barbatia setigera } \\
\text { (Reeve, 1844) }\end{array}$ & - & - & - & - & - & - & $*$ & - & - & - \\
\hline $\begin{array}{l}\text { Brachidontes variabilis } \\
\quad \text { (Krauss, 1848) }\end{array}$ & $*(3)$ & $*(1)$ & + & * & $*(1)$ & * & * & * & $* *$ & - \\
\hline $\begin{array}{l}\text { Carditopsis majeeda } \\
\quad \text { (Biggs, 1973) }\end{array}$ & $* *$ & $* *$ & $*$ & $*$ & $*$ & $* *$ & $* *$ & - & $*$ & $*$ \\
\hline $\begin{array}{l}\text { Fulvia fragile } \\
\qquad \text { (Forskal, 1775) }\end{array}$ & - & - & - & - & - & - & - & - & - & - \\
\hline $\begin{array}{l}\text { Tellina arsinoensis } \\
\quad \text { (Issel, 1869) }\end{array}$ & * & $*$ & * & * & * & $* *$ & $*$ & - & * & - \\
\hline $\begin{array}{l}\text { Dosinia ceylonica } \\
\quad \text { (Dunker, 1865) }\end{array}$ & $* * *$ & $* *$ & $* *$ & $* *$ & $* *$ & $* * *$ & $* *$ & * & $* *$ & * \\
\hline \multicolumn{11}{|l|}{ Gastropods } \\
\hline $\begin{array}{l}\text { Osilinus kotschyi } \\
\quad \text { (Philippi, 1849) }\end{array}$ & $*$ & - & - & - & - & - & - & - & - & $*$ \\
\hline Trochidae juvenile & - & - & - & - & - & - & - & - & $*$ & - \\
\hline $\begin{array}{l}\text { Phasianella solida } \\
\text { (Born, 1778) }\end{array}$ & - & - & - & - & - & $*$ & - & - & - & - \\
\hline $\begin{array}{l}\text { Tricolia fordiana } \\
\text { (Pilsbry, 1886) }\end{array}$ & - & - & - & - & - & - & - & - & $* *$ & - \\
\hline $\begin{array}{l}\text { Cerithideopsilla conica } \\
\quad \text { (Blainville, 1826) }\end{array}$ & $* * *$ & $* *$ & * & ** & $*$ & $* * *$ & $* *$ & - & $*$ & - \\
\hline $\begin{array}{l}\text { Cerithium scabridum } \\
\text { (Philippi, 1848) }\end{array}$ & - & - & - & - & - & - & - & - & $*$ & - \\
\hline $\begin{array}{l}\text { Obtortio pupoides } \\
\quad \text { (A. Adams, 1860) }\end{array}$ & - & - & - & - & - & - & - & - & $?$ & - \\
\hline Rissoidae worn & - & - & - & * & - & - & - & - & - & - \\
\hline Serpulorbis sp. & - & - & - & - & - & - & - & - & $*$ (juv) & - \\
\hline $\begin{array}{l}\text { Mitrella blanda } \\
\quad \text { (Sowerby, 1844) }\end{array}$ & $* *$ & - & - & $*$ & - & $*$ & - & - & $*$ & - \\
\hline Odostomia sp. & $*$ & - & - & - & * & $*$ & $*$ & - & * & - \\
\hline $\begin{array}{l}\text { Retusa tarutana } \\
\quad \text { (Smythe, 1979) }\end{array}$ & $* * *$ & ** & $*$ & $* *$ & $*$ & $* * *$ & $*$ & - & $*$ & - \\
\hline
\end{tabular}

Key: ${ }^{*}=1-10$ specimens, ${ }^{* *}=10-50$ specimens, ${ }^{* * *}=>50$ specimens. Bivalvia counted umbos ( $+=$ present but no umbos); gastropoda counted apices. substrates is found more commonly in samples indicating that some sheltered, hard substrates were available for attachment more generally. One final mollusc species, a specimen of Pinctada (pearl oyster) collected during the excavation, came from the main shelly band next to the skull and is also an indicator of a hard substrate onto which it attaches. This may be because it was attached to the skull or simply, being a large shell, came to rest in this relatively coarse-grained sediment.

In summary, the mollusc faunas and particularly the abundance of Cerithideopsilla indicate very shallow-water to intertidal environments. The fauna does not include any of the chemosymbiotic bivalve species often associated with decaying whale carcasses sunken in deeper water (e.g those described by Deming et al., 1997).

\subsection{Cirripedes}

During the excavation of the whale remains occasional large barnacles were found (Fig. 8). These barnacles were identified as the sessile barnacle Coronula diadema due to their crown-shape with convex ribs (Darwin, 1854; Pilsbury, 1916), distinguishing them from Coronula reginae with a more globulo-conical or depressed shape and more flattened, longitudinal ribs. There are fossil taxa in the genus Coronula such as Coronula barbara and Coronula bifida, dating from the Pliocene of the Mediterranean and British Isles (Bianucci et al., 2006a), although it is doubtful that these are relevant in this instance. Both $C$. diadema and $C$. reginae are species associated with cetaceans. The barnacles at Musaffah were found associated with whale bones, generally within half a meter of the bones, and particularly along the length of the left mandible. The latter would appear to be consistent with the positions of barnacles on the skin of humpback whales as "attached to the underlip, throat, the front edge of the fins, and the flukes" (Pilsbury, 1916).

The range of barnacle diameters at Musaffah is $21.2-38.3 \mathrm{~mm}$ $(N=3)$ and heights are $13.5-37.4 \mathrm{~mm}(N=4)$. Compared to the dimensions described in Bianucci et al., (2006a,b) (diameter range $=21-82 \mathrm{~mm}$; average diameter $=59 \mathrm{~mm} ; N=58$ ), the diameter of the barnacles at Musaffah appears smaller than average, although the small number recovered makes the comparison unreliable. The reasons for this are unclear. Furthermore, the barnacles show no obvious signs of encrusting or boring organisms

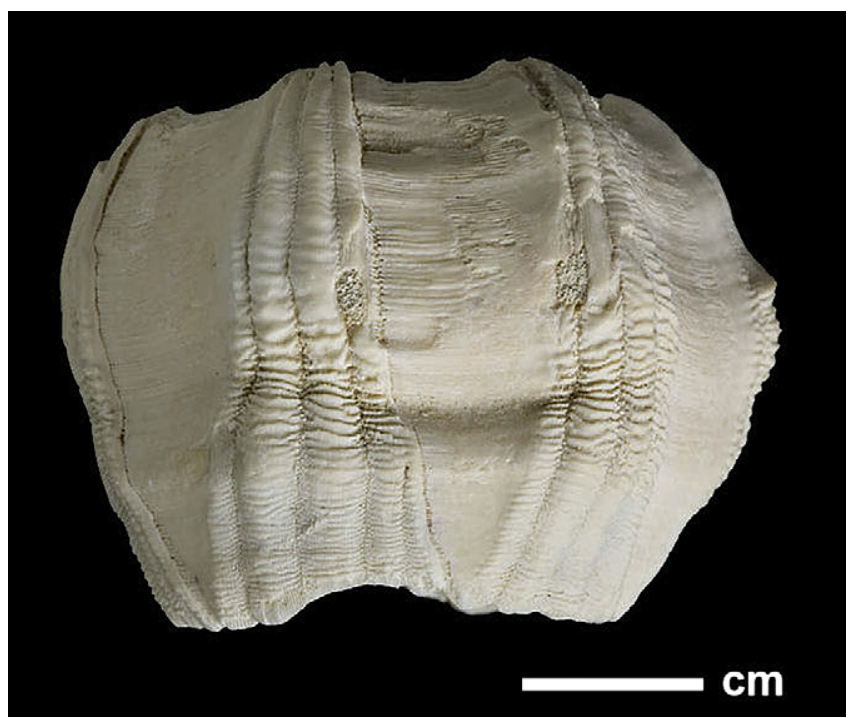

Fig. 8. Plate of a whale barnacle Coronula diadaema in lateral view from the Musaffah excavation (scale bar is $1 \mathrm{~cm}$ ). (Photos: NHM Photo Unit). 
(as seen by Bianucci et al., 2006b) which supports their association with the whale remains at Musaffah and suggests that the remains were not exposed for long prior to burial.

C. diadema is mainly associated with humpback whales today (Pilsbury, 1916; Nilsson-Cantell, 1978). Indeed Bianucci et al., (2006b) have used the occurrence of the C. diadema in the PlioPleistocene Canoa and Tablazo Formation deposits in Ecuador to infer the presence of humpback whales in the Canoa Basin at that time. Furthermore, they suggested that the presence of humpback whales must have been sufficiently long lasting for a build-up of such an exceptional assemblage of Coronula remains and that they may have been breeding in the basin. Bianucci et al. (2006b) acknowledged, however, that the $C$. diadema can be found on other whale species such as fin, blue, right and sperm whales. For example Nilsson-Cantell (1939) reported C. diadema as present on the northern bottle-nosed whale Hyperoodon ampullatus off the Faroes, with further accounts of this barnacle on sperm whales Physeter catodon (Hiro, 1935), southern right whale Eubalaena australis (Barnard, 1924) and blue whales B. musculus (NilssonCantell, 1939). Scarff (1986) also reported that C. diadema on a southern right whale. In this instance, an individual southern right whale was seen off Half Moon Bay, California with approximately 300 coronuline barnacles on its skin surface. The barnacles in this instance included both $C$. diadema and $C$. reginae. The suggestion was that the barnacles on this southern right whale had been acquired during association with humpback whales, although it could have been from any one of several species of large whale. The identification of the whale remains at Musaffah, as a potential humpback, is therefore consistent with the literature on the modern occurrences of the associated barnacle C. diadema. It would be interesting to know the relationship between $C$. diadema barnacles with the humpback population represented by the remains at Musaffah. This is because the life cycle of these barnacles is thought to relate to the migration routes of humpback whales (Bianucci et al., 2006a) and the nearest modern humpback population (in the Arabian Sea) is claimed to be relatively sedentary (Mikhalev, 1997). This may suggest that the Arabian Sea humpback whales are less sedentary than suggested by Mikhalev (1997) or that the $C$. diadema barnacles associated with the Arabian Sea humpback whales may represent an isolated population with respect to conspecifics.

\subsection{Microfossils - ostracoda and foraminifera}

Ten microfossil sub-samples (11 if the fragment of cemented layer is included) were taken from different locations and sediment facies surrounding the whale remains at Musaffah. Table 7 shows the ostracod and foraminifera species represented in the samples and photographs of examples of the different taxa are shown in Figs. 9 and 10.

The ostracod assemblages from the different samples represented different facies and locations around the whale skeleton although they differed little from each other in composition. The basis for interpretation of the ostracods from the Musaffah whale site is the analysis by Bate (1971) of Recent Abu Dhabi near-shore and lagoonal ostracods. In Bate's study the following assemblages were defined including the near-shore shelf, back reef, tidal delta, lagoon channels, lagoon terrace (outer lagoon), lagoon terrace (central lagoon), lagoon terrace (inner lagoon) and tidal pools.

The most common taxon in all the Musaffah samples is a species of Cyprideis which, according to Bate (1971), is a common lagoonal species in the hypersaline lagoons of Abu Dhabi today (as recorded before 1971). The species is associated with both the lagoon terrace and tidal pools, and usually found living within the loose structure of the calcareous algae Jania. In Europe, species of Cyprideis are often associated with brackish water conditions (e.g. C. torosa), but in the Arabian Gulf these animals are adapted to hypersaline environments. The other taxon which is found in the lagoons, and particularly characteristic of the central lagoon, is Moosella sp. (Bate, 1971) which is a large ornamental form. Paijenborchellina was found by Bate (1971) in recent near-shore shelf, lagoonal channel, and central and inner lagoonal terrace assemblages, although it was noted as varying morphologically according to environment. Loxoconcha is represented at Musaffah by three distinct species which differ in the degree to which they are ornamented. Finally, Xestoleberis is closely associated with seaweed and sea grass and has a wide tolerance of salinity levels. The genus was found in all ostracod assemblages examined by Bate (1971).

The ostracod fauna at Musaffah is one characteristic of a recent lagoonal terrace rather than a tidal-channel (Table 7). This would imply that the sediments were deposited in relatively shallow water, as low as $2 \mathrm{~m}$, with possible exposure at low tide. Ostracod assemblage compositions in the near-shore and lagoonal environments are controlled by relative salinity and water depth (Bate, 1971). This includes a varying effect caused by differences in bottom sediment type and water turbulence between the outer to the central lagoon. High salinities are today correlated with low ostracod taxon diversity, albeit with large numbers of individuals of the few species that are present (Bate, 1971). The latter scenario would explain the low diversity found in the sediments here described although the sediments around the whale display diversities as low as those in tidal pools today (Table 7). It may be therefore that under the climates of ca 5000 year ago salinity levels in the

Table 7

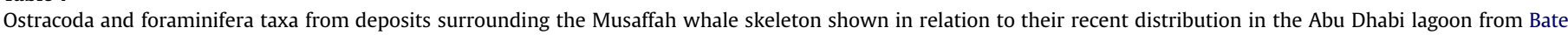
(1971) and Murray (1970).

\begin{tabular}{|c|c|c|c|c|c|c|c|c|c|}
\hline \multirow[t]{2}{*}{ Taxon } & \multirow{2}{*}{$\begin{array}{l}\text { Deposits surrounding } \\
\text { the whale }\end{array}$} & \multirow{2}{*}{$\begin{array}{l}\text { Near } \\
\text { shore }\end{array}$} & \multirow{2}{*}{$\begin{array}{l}\text { Back } \\
\text { reef }\end{array}$} & \multirow{2}{*}{$\begin{array}{l}\text { Tidal } \\
\text { delta }\end{array}$} & \multirow{2}{*}{$\begin{array}{l}\text { Lagoonal } \\
\text { channel }\end{array}$} & \multicolumn{3}{|c|}{ Lagoon terrace } & \multirow{2}{*}{$\begin{array}{l}\text { Tidal } \\
\text { pool }\end{array}$} \\
\hline & & & & & & Outer & Central & $\overline{\text { Inner }}$ & \\
\hline \multicolumn{10}{|l|}{ Ostracods } \\
\hline Cyprideis & + & - & - & - & - & + & + & + & + \\
\hline Paijenborchellina & + & + & + & + & + & - & + & + & - \\
\hline Moosella & + & - & - & - & + & - & + & - & - \\
\hline Loxoconcha & + & + & + & + & + & + & + & + & - \\
\hline Xestolebris & + & + & + & + & + & + & + & + & + \\
\hline \multicolumn{10}{|l|}{ Foraminifera } \\
\hline Ammonia & + & $\mathrm{N} / \mathrm{A}$ & $\mathrm{N} / \mathrm{A}$ & - & - & - & $\mathrm{N} / \mathrm{A}$ & - & $\mathrm{N} / \mathrm{A}$ \\
\hline Elphidium & + & $\mathrm{N} / \mathrm{A}$ & $\mathrm{N} / \mathrm{A}$ & - & - & - & $\mathrm{N} / \mathrm{A}$ & + & $\mathrm{N} / \mathrm{A}$ \\
\hline Quinqueloculina & + & $\mathrm{N} / \mathrm{A}$ & $\mathrm{N} / \mathrm{A}$ & + & - & + & $\mathrm{N} / \mathrm{A}$ & - & $\mathrm{N} / \mathrm{A}$ \\
\hline Peneroplis & + & $\mathrm{N} / \mathrm{A}$ & $\mathrm{N} / \mathrm{A}$ & + & + & - & $\mathrm{N} / \mathrm{A}$ & + & $\mathrm{N} / \mathrm{A}$ \\
\hline
\end{tabular}

${ }^{a}$ MUS 3, 4, 5, 6, 7, 8, 10, 14, 15, 27; N/A - not applicable as not sampled for foraminifera by Murray (1970). 


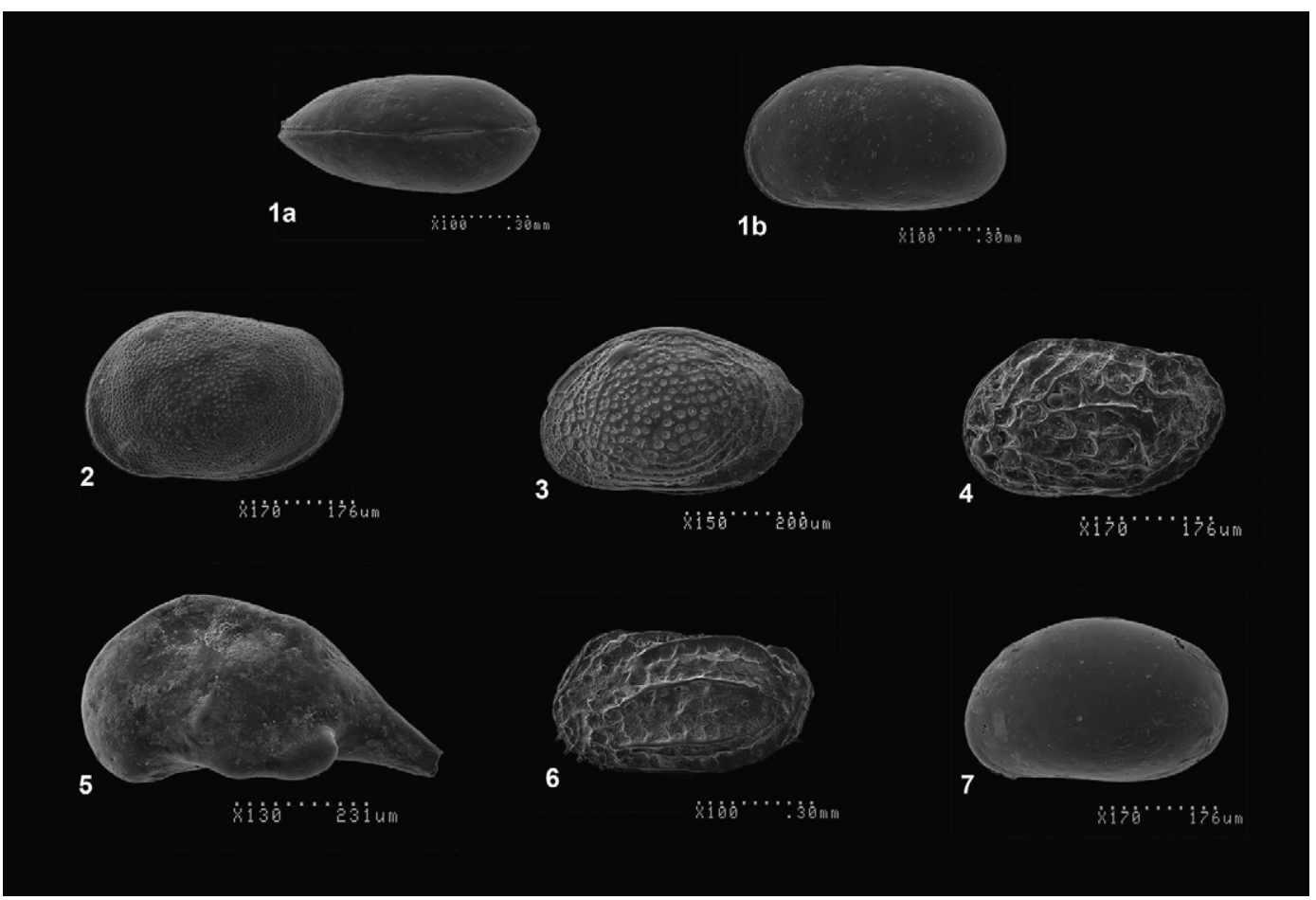

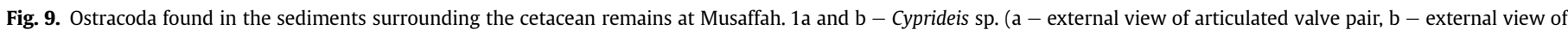
single valve); 2 - Loxoconcha sp. 1; 3 - Loxoconcha sp. 2; 4 - Loxoconcha sp. 3; 5 - Paijenborchellina sp.; 6 - Moosella sp.; 7 - Xestolebris sp. (Photos: NHM Photo Unit).

contemporary lagoons were even higher. It should be mentioned, however, that this is contradicted by other evidence suggesting that the barrier islands were much smaller in the mid-Holocene (Evans et al., 1964, 1969; Purser and Evans, 1973; Strohmenger et al., 2010). There is also a suggestion that the wave energy was much greater at the time and created the contemporaneous storm beaches and that the lagoons were far less restricted and hence more open and so less prone to higher salinities (Purser and Evans, 1973; Strohmenger et al., 2011). These contradictions will eventually need reconciling.

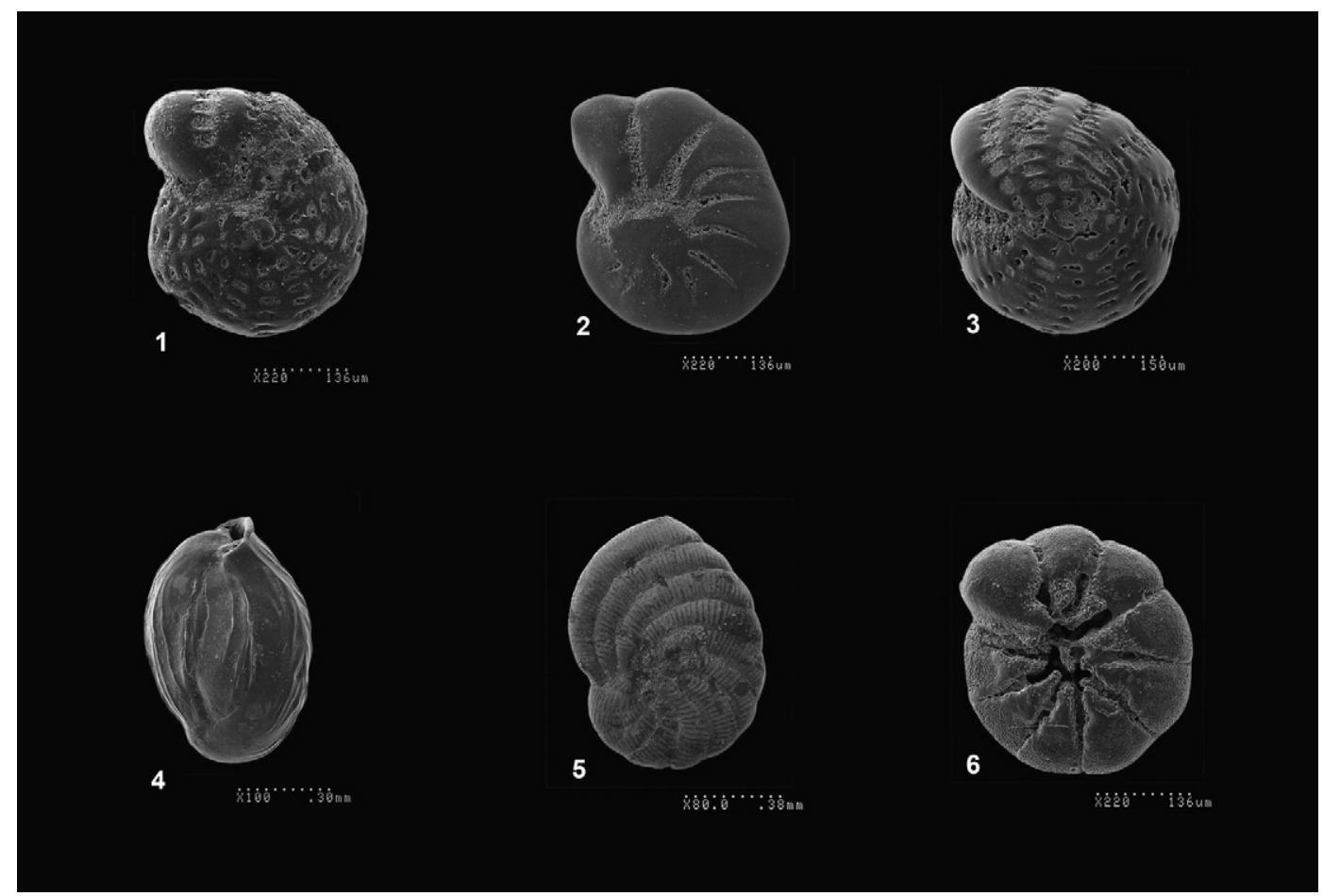

Fig. 10. Foraminifera found in the sediments surrounding the cetacean remains at Musaffah. 1 - Elphidium sp. 1; 2 - Elphidium sp. 2; 3 - Elphidium sp. 3; 4 - Quinqueloculina sp.; 5 - Peneroplis sp.; 6 - Ammonia sp. (Photos: NHM Photo Unit)

Please cite this article in press as: Stewart, J.R., et al., Biotically constrained palaeoenvironmental conditions of a mid-Holocene intertidal lagoon on the southern shore of the Arabian Gulf: evidence associated with a whale skeleton at Musaffah, Abu Dhabi, UAE, Quaternary Science Reviews (2011), doi:10.1016/j.quascirev.2011.09.004 
The foraminifera from the recent hypersaline lagoons of $\mathrm{Abu}$ Dhabi were studied by Murray (1970). Peneroplis planatus was found to be the most abundant living species and the most common dead form in recent carbonate sediments. Peneroplis is also well represented in the sediments around the whale. Other taxa present at the Musaffah whale site include Ammonia, Elphidium and Quinqueloculina. Of the latter, Ammonia is absent from recent live and dead assemblages in Abu Dhabi lagoon. Quinqueloculina is found today in the tidal delta and the outer lagoon, while Elphidium is only found in the inner lagoon (Murray, 1970). These taxa in themselves are not very informative about the part of a lagoonal system represented at Musaffah, although the low diversity seems to indicate that the lagoonal facies represented is one with relatively shallow water and/or higher salinities. This is similar to the result of the ostracod analysis. The other perspective to which the foraminifera can contribute is the substrate on which they live. Generally foraminifera prefer to live on vegetation such as seaweeds and sea grasses, rather than on bare carbonate sediment surfaces, and Peneroplis was found to dominate plants in the recent lagoon (Murray, 1970). It is therefore probable that aquatic vegetation was present in the vicinity of the whale and the rootlet bed that was described adjacent to the left mandible may be further evidence of that.

In summary, the microfossils from the sediments at Musaffah have a very much lower diversity than found in lagoons in the same area today. Reasons for this could be several, but a much higher salinity would perhaps seem the most probable (but see Purser and Evans, 1973; Strohmenger et al., 2011), especially as the dating (approximately $5200{ }^{14} \mathrm{C}$ yrs BP) coincides with a time just after the Arabia Peninsula had become more arid (6000 yrs BP) and its dune systems had started to develop (Bray and Stokes, 2004).

\section{Discussion and conclusion}

The analyses of the multi-proxy data from the excavation site have shed light on the timing, environment of deposition, taphonomic history and taxonomic identity of the whale remains at Musaffah in Abu Dhabi. The dates immediately below the whale remains (ca $5200{ }^{14} \mathrm{C}$ yrs BP) are consistent with, and correspond to, the dates that are known for the sea-level highpoint in the Arabian Gulf during the mid-Holocene (Kennett and Kennett, 2006 and references therein). The sediments surrounding the whale consist of a series of sabkha-overprinted intertidal to shallow subtidal deposits. The horizon of the whale itself, a series of shelly sands, is interpreted as representing a tidal-channel deposit. The microfaunal proxies (ostracods and foraminifera) suggest a shallowwater environment, possibly representing the surface of a tidal flat indicating that the tidal-channel is likely to have been in shallow water with higher salinities than that recorded from modern lagoons on the basis of their taxonomic constituents and impoverished species composition (Bate, 1971). Therefore, the comparisons with lagoonal faunas today would suggest higher salinities existed in the mid-Holocene lagoon at Musaffah.

The whale remains at Musaffah are likely to belong to a single individual and, based on the position of the remains recovered, appear to represent parts of an entire skeleton. The species of the whale cannot yet be determined with certainty although the skeleton appears to belong to that of a humpback whale $M$. novaeangliae. Accompanying the whale remains were barnacles of the species $C$. diadema that only live on the skin of cetaceans and prevalently on humpback whales. The presence of the whale is indicative of a link between the environments represented at Musaffah and the open ocean. As far as we know this skeleton represents the only Holocene whale skeleton identified from the Arabian Gulf.
The Abu Dhabi sabkha, along the south-eastern coast of the Arabian Gulf, is the best-known modern example of such sediments and has therefore featured in many studies over the last 40 years, as well as forming the most general example used in text books. The present paper also provides a detailed palaeoecological study of these deposits and so describing biota that lived in this environment during the mid-Holocene high sea-level stand. The findings of the cetacean remains at Musaffah have given a new focus of study for an already well-known sedimentary sequence and added an unexpected perspective to these deposits. The analysis suggests that other vertebrate remains could be found in these and similar deposits in the future. However, the most interesting result of this analysis is that it has demonstrated the likelihood that lagoonal water in the mid-Holocene had higher salinities than today as this may well have been linked to the onset of continental aridity of Arabia which began 6000 years ago (Bray and Stokes, 2004).

\section{Acknowledgements}

Work during the 2008 season was undertaken under the aegis of the Environment Agency - Abu Dhabi, EAD, and was funded by the Abu Dhabi National Oil Company, ADNOC. Logistic and other support, including help with excavation, was provided by the Department of Historic Environment of the Abu Dhabi Authority for Culture and Heritage, ADACH, and we particularly thank Aqil Ahmed of the Historic Environment Department for helping Mark Beech with total station surveying. Khalil Al-Mehsin (ADNOC), Abdulla Al-Mansoori, Ismail Al-Hosani, Ali Al-Shamry (ADCO), and Hesham Shebl helped with the sedimentological analyses. We would like to thank Environment agency - Abu Dhabi for access to the UAE National Cetacean Database.

We would also like to thank the Natural History Museum Photographic Unit and in particular Phil Crabb, Phil Hurst and Kevin Webb for the photography in Figs. 7-10. Harry Manley of Bournemouth University is thanked for further help with Fig. 8. Figs. 1, 4 and 5 are reproduced by kind permission of the Editor of $\mathrm{Geo}$ Arabia. All the site photos were taken by the excavation team (S.A., N.L. and J.S).

\section{References}

Alsharhan, A.S., Kendall, C.G.St.C., 1994. Depositional setting of the Upper Jurassic Hith anhydrite of the Arabian Gulf: an analog to Holocene evaporites of the United Arab Emirates and Lake MacLeod of Western Australia. Am. Assoc. Pet. Geol. Bull. 78, 1075-1096.

Alsharhan, A.S., Kendall, C.G.St.C., 2002. Holocene carbonate/evaporites of Abu Dhabi, and their Jurassic ancient analogs. In: Barth, H.-J., Böer, B. (Eds.), Sabkha Ecosystems. The Arabian Peninsula and Adjacent Countries, vol. I. Kluwer Academic Publishers, Dordrecht, pp. 187-202.

Alsharhan, A.S., Kendall, C.G.St.C., Whittle, G.L., 1998. Field Trip Guide to Examine the Holocene Carbonate/Evaporites of Abu Dhabi, United Arab Emirates. U.A.E. University Publications Department, Al Ain.

Andrews, R.C., 1916. The sei whale (Balaenoptera borealis Lesson). Mem. Am. Mus. Nat. Hist. 1 (6), 289-388.

Baldwin, R.M., Gallagher, M.D., Van Waerebeek, K., 1999. A review of cetaceans from waters off the Arabian Peninsula. In: Fisher, M., Spalton, A., Gazanfar, S. (Eds.), Oman's Natural History. Backhuys Publishers, Leiden, pp. 161-189.

Bate, R.H., 1971. The distribution of recent ostracoda in the Abu Dhabi Lagoon, Persian Gulf. Bull. Centre Rech. Pau. - SNPA 5 (Suppl.), 239-256.

Barnard, M.A., 1924. Contribution to the crustacean fauna of South Africa. Nr. 7: Cirripedia. Ann. S. Afr. Mus. 20, 1-103.

Beech, M.J., 2010. Mermaids of the Arabian Gulf: archaeological evidence for the exploitation of dugongs from prehistory to the present. Liwa (J. Nat. Centre Document. Res.) 2 (3), 3-18.

Bianucci, G., Landini, W., Buckeridge, J., 2006a. Whale barnacles and Neogene cetacean migration routes. N. Z. J. Geol. Geophys. 49 (1), 115-120.

Bianucci, G., Di Celma, C., Landini, W., Buckeridge, J., 2006b. Palaeoecology and taphonomy of an extraordinary whale barnacle accumulation from the PlioPleistocene of Ecuador. Palaeogeogr. Palaeoclimatol. Palaeoecol. 242 (3-4), 326-342. 
Bontognali, T.R.R., Vasconcelos, C., Warthmann, R.J., Dupraz, C., Bernasconi, S.M., McKenzie, J.A., 2008. Microbes produce nanobacteria-like structures, avoiding cell entombment. Geology 36, 663-666.

Bontognali, T.R.R., Vasconcelos, C., Warthmann, R.J., Bernasconi, S.M., Dupraz, C., Strohmenger, C.J., McKenzie, J.A., 2010. Dolomite formation within microbial mats in the sabkha of Abu Dhabi (UAE). Sedimentology 57, 824-844.

Bosselaers, M., Herman, J., Hoedemakers, K., Lambert, O., Marquet, R., Wouters, K., 2004. Geology and palaeontology of a temporary exposure of the Late Miocene Deurne Sand Member in Antwerpen (N. Belgium). Geol. Belg. 7 (1-2), 27-39.

Bray, H.E., Stokes, S., 2004. Temporal patterns of arid-humid transitions in the south-eastern Arabian Peninsula based on optical dating. Geomorphology 59, 271-280.

Butler, G.P., 1969. Modern evaporite deposition and geochemistry of co-existing brines, the sabkha, Trucial Coast, Arabian Gulf. J. Sediment. Petrol. 39, 70-89.

Butler, G.P., 1970. Holocene gypsum and anhydrite of the Abu Dhabi sabkha, Trucial Coast: an alternative explanation of origin. Third Symposium on Salt. North Ohio Geological Society 1, 120-152.

Butler, G.P., Harris, P.M., Kendall, C.G.St.C., 1982. Recent evaporites from the Abu Dhabi coastal flats. In: Handford, C.R., Loucks, R.G., Davies, G.R. (Eds.), Depositional and Diagenetic Spectra of Evaporites - A Core Workshop. SEPM (Society for Sedimentary Geology), Core Workshop, vol. 3, pp. 33-64.

Curtis, R., Evans, G., Kinsman, D.J.J., Shearman, D.J., 1963. Association of dolomite and anhydrite in the recent sediments of the Persian Gulf. Nature 197, 679-680.

Darwin, C.R., 1854. On the Sub-class Cirripedia, with Figures of All the Species. The Ray Society, London.

Deméré, T.A., 1986. The fossil whale, Balaenoptera davidsonii (Cope 1872), with a review of other Neogene species of Balaenoptera (Cetacea: Mysticeti). Mar. Mamm. Sci. 2, 277-298.

Deméré, T.A., Berta, A., McGowen, M.R., 2005. The taxonomic and evolutionary history of fossil and modern balaenopterid mysticetes. J. Mamm. Evol. 12, 99-143.

Deming, J.W., Rysenbach, A.-L., Macko, S.A., Smith, C.R., 1997. Evidence for the microbial basis of a chemoautotrophic invertebrate community at a whale fall on the deep seafloor: bone-colonizing bacteria and invertebrate endosymbionts. Microsc. Res. Tech 37, 162-170.

Edwards, A., Bush, P.E., Evans, G., 1986. Salt and contaminant flux in the Abu Dhab Lagoon. In: Rapports et Procès-Verbaux des Réunion, Conseil International pour l'Exploration de la Mer, vol. 186 412-422.

Esparante, R., Muñiz Guinea, F., Nick, K.E., 2009. Taphonomy of a Mysticeti whale in the Lower Pliocene Huelva Sands Formation (Southern Spain). Geol. Acta, 489-505.

Evans, G., 1995. The Arabian Gulf: a modern carbonate-evaporite factory: a review. Cuadernos de Geología Ibérica 19, 61-96.

Evans, G., Kendall, C.G.S.C., d'E. Skipwith, P., 1964. Origin of the coastal flats, the sabkha, of the Trucial Coast of the Persian Gulf. Nature, 759-761.

Evans, G., Kirkham, A., 2002. The Abu Dhabi sabkha. In: Barth, H.-J., Böer, B. (Eds.) Sabkha Ecosystems. The Arabian Peninsula and Adjacent Countries, vol. I. Kluwer Academic Publishers, Dordrecht, pp. 7-20.

Evans, G., Kirkham, A., Carter, R.A., 2002. Quaternary development of the United Arab Emirates Coast: new evidence from Marawah Island, Abu Dhabi. GeoArabia 7, 441-458.

Evans, G., Schmidt, V., Bush, P., Nelson, H., 1969. Stratigraphy and geologic history of the Sabkha, Abu Dhabi, Persian Gulf. Sedimentology 12, 145-159.

Fordyce, R.E., Barnes, L.G., 1994. The evolutionary history of Whales and Dolphins. Annu. Rev. Earth Planet. Sci. 22, 419-455.

Gardiner, M., Stewart, J.R., Bell, G., 1999. Anglo-Saxon whale exploitation: some evidence from Dengemarsh, Lydd, Kent. Med. Arch. 42, 96-101.

Hiro, F., 1935. The fauna of Akkeshi Bay II. Cirripedia. J. Fac. Sci. Hokkaido Univ., Ser. VI Zool. 4, 213-229.

Kassler, P., 1973. The structural and geomorphic evolution of the Persian Gulf. In: Purser, B.H. (Ed.), The Persian Gulf. Holocene Carbonate Sedimentation and Diagenesis in a Shallow Epicontinental Sea. Springer-Verlag, Berlin, pp. 11-32.

Kazar, E., Venczel, M., 2003. Kentriodontid remains (Cetacea: Odontoceti) from the Miocene of Bihor County Romania. Nymphaea, Folia Naturae Bihariae 30 $39-66$.

Kendall, C.G.St.C., d'E. Skipwith, P.A., 1968. Recent algal mats of a Persian Gulf lagoon. J. Sediment. Petrol. 38, 1040-1058.

Kendall, C.G.St.C., d'E. Skipwith, P.A., 1969. Geomorphology of a recent shallowwater carbonate province: Khor Al Bazam, Trucial Coast, Southwest Persian Gulf. Geol. Soc. Am. Bull. 80, 865-892.

Kendall, C.G.St.C., Warren, J.K., 1988. Peritidal evaporites and their sedimentary assemblages. In: Schreiber, B.C. (Ed.), Evaporites and Hydrocarbons. Columbia University Press, New York, pp. 66-138.

Kendall, C.G.St.C., Sadd, J.L., Alsharhan, A., 1994. Holocene marine cement coatings on beach-rocks of the Abu Dhabi coastline (UAE.); analogs for cement fabrics in ancient limestones. Carbonate. Evaporite 9, 119-131.

Kendall, C.G.St.C., Alsharhan, A.S., Cohen, A., 2002. The Holocene tidal flat complex of the Arabian Gulf coast of Abu Dhabi. In: Barth, H.-J., Böer, B. (Eds.), Sabkha Ecosystems. The Arabian Peninsula and Adjacent Countries, vol. I. Kluwer Academic Publishers, Dordrecht, pp. 21-35.

Kenig, F., 1991. Sédimentation, distribution et diagenèse de la matière organique dans un environnement carbonaté hypersalin: le système lagune-sabkha d'Abu Dhabi. PhD thesis, Université d'Orléans, Orleans, France.

Kenig, F., 2011. Distribution of organic matter in the transgressive and regressive Holocene sabkha sediments of Abu Dhabi, United Arab Emirates. In:
Alsharhan, A., Kendall, C.G.St.C. (Eds.), Quaternary Carbonate and Evaporite Sedimentary Facies and Their Ancient Analogues. International Association of Sedimentologists, Special Publication, vol. 42, pp. 277-298.

Kenig, F., Huc, A.Y., Purser, B.H., Oudin, J.L., 1990. Sedimentation, distribution and diagenesis of organic-matter in a recent carbonate environment, Abu-Dhabi, UAE. Org. Geochem. 16, 735-747.

Kennett, D.J., Kennett, J.P., 2006. Early state formation in Southern Mesopotamia: sea levels, shorelines, and climate change. J. Islands Coastal Archaeol. 1, 67-99.

Kinsman, D.J.J.,1969. Modes of the formation, sedimentary associations, and diagnostic features of shallow-water and supratidal evaporites. AAPG Bull. 53, 30-840.

Kirkham, A., 1997. Shoreline evolution, aeolian deflation and anhydrite distribution of the Holocene, Abu Dhabi. GeoArabia 2 (4), 403-416.

Kirkham, A., 1998. A quaternary proximal foreland ramp and its continental fringe, Arabian Gulf, UAE. In: Wright, V.P., Burchette, T.P. (Eds.), Carbonate Ramps. Geological Society London, Special Publication, vol. 149, pp. 15-41.

Lambeck, K., 1996. Shoreline reconstructions for the Persian Gulf since the last glacial maximum. Earth Planet. Sci. Lett. 142, 43-57.

Lambeck, K., Esat, T.M., Potter, E.-K., 2002. Links between climate and sea levels for the past three million years. Nature 419, 199-206.

Lydekker, R. 1887. The Cetacea of the Suffolk Crag. Q. J. Geol. Soc. 43, 7-18.

Malaquias, M.A.E., Berecibar, E., Reid, D.G., 2009. Reassessment of the trophic position of Bullidae (Gastropoda: Cephalaspidea) and the importance of diet in the evolution of cephalaspidean gastropods. J. Zool. 277, 88-97.

McKenzie, J.A., 1981. Holocene dolomitization of calcium carbonate sediments from the coastal sabkhas of Abu Dhabi, U.A.E.: a stable isotope study. J. Geol. 89, 185-198.

McKenzie, J.A., Hsü, K.J., Schneider, J.F., 1980. Movement of subsurface waters under the sabkha, Abu Dhabi, UAE, and its relation to evaporative dolomite genesis. In: Zenger, D.H., Dunham, J.B., Ethington, R.L. (Eds.), Concepts and Models of Dolomitization. SEPM (Society for Sedimentary Geology), Special Publication, vol. 28 , pp. $11-30$

Mead, J.G., Brownell Jr., R.L., 2005. Order Cetacea. In: Wilson, D.E., Reeder, D.M. (Eds.), Mammals Species of the World: a Taxonomic and Geographic Reference. Smithsonian Institution Press, Washington and London, pp. 349-364.

Mikhalev, Y.A., 1997. Humpback whales Megaptera novaeangliae in the Arabia Sea. Mar. Ecol. Prog. Ser. 149, 13-21.

Mulville, J., 2002. The role of cetacea in prehistoric and historic Atlantic Scotland. Int. J. Osteoarchaeol. 12, 34-48.

Murray, J.W., 1970. The foraminifera of the hypersaline Abu Dhabi lagoon, Persian Gulf. Lethaia 3, 51-68.

Nagasawa, K., Mitani, Y., 2004. A humpback whale, Megaptera novaeangliae (Borowski, 1781), from the Pleistocene Kioroshi Formation of Inba-mura, Chiba Prefecture, central Japan. Paleontol. Res. 8, 155-165.

Nilsson-Cantell, C.-A., 1939. Thoracic cirripeds collected in 1925-36. Discovery Rep. $18,223-238$.

Nilsson-Cantell, C.-A., 1978. Cirripedia thoracica and acrothoracica. In: Marine Invertebrates of Scandinavia, No. 5. Universitetsforlaget, Oslo, Norway.

Omura, H., 1959. Bryde's whale from the coast of Japan. Sci. Rep. Whales Res. Inst. $14,1-33$.

Omura, H., Ichihara, T., Kasuya, T., 1970. Osteology of pygmy blue whale with additional information on external and other characteristics. Sci. Rep. Whales Res. Inst. 22, 1-27.

Omura, H., 1975. Osteological study of the minke whale from the Antarctic. Sci. Rep. Whales Res. Inst. 27, 1-36.

Park, P.K., 1977. The preservation potential of some recent stromatolites. Sedimentology 24, 485-506.

Peebles, R.G., Shaner, M., Kirkham, A., 1995. Arid coastline depositional environments. International Field Seminar. In: A Fieldguide to the Abu Dhabi Coast, United Arab Emirates. American Association of Petroleum Geologists.

Pierson, B.J., Aspinall, S., Al-Mehsin, K., 2006. Fossil whale bones in Abu Dhabi's coastal sabkha. First Break 4, 3-4.

Pierson, B.J., Aspinall, S., Al-Mehsin, K., 2008. Fossil whale skeleton in Abu Dhabi's coastal sabkha. Abstracts of the first and second international conference on evaporites, 2004 and 2006, Abu Dhabi, United Arab Emirates. GeoArabia 13 (2), 170.

Pilsbury, H.A. 1916. The Sessile Barnacles (Cirripedia) Contained in the Collection of the U.S. National Museum: Including a Monograph on the American Species. Smithsonian, Washington.

Purser, B.H., 1973. The Persian Gulf. Holocene Carbonate Sedimentation and Diagenesis in a Shallow Epicontinental Sea. Springer-Verlag. Berlin.

Purser, B.H., Seibold, E., 1973. The principle environmental factors influencing Holocene sedimentation and diagenesis in the Persian Gulf. In: Purser, B.H. (Ed.), The Persian Gulf. Holocene Carbonate Sedimentation and Diagenesis in a Shallow Epicontinental Sea. Springer-Verlag, Berlin, pp. 1-9.

Purser, B.H., Evans, G., 1973. Regional sedimentation along the Trucial Coast, SE Persian Gulf. In: Purser, B.H. (Ed.), The Persian Gulf. Holocene Carbonate Sedimentation and Diagenesis in a Shallow Epicontinental Sea. Springer-Verlag, Berlin, pp. 211-231.

Rohland, N., Siedel, H., Hofreiter, M., 2010. A rapid column-based ancient DNA extraction method for increased sample throughput. Mol. Ecol. Resour. 10, $677-683$.

Sanford, W.E., Wood, W.W., 2001. Hydrology of the coastal sabkhas of Abu Dhabi, United Arab Emirates. Hydrogeol. J. 9, 358-366.

Scarff, J.E., 1986. Occurrence of the barnacles Coronula diadema, C. reginae and Cetopirus complanatus (Cirripedia) on right whales. Sci. Rep. Whales Res. Inst. 37, 129-153. 
Shearman, D.J., 1983. Syndepositional and late diagenetic alteration of primary gypsum to anhydrite. In: Sixth International Symposium on Salt, Toronto, 1, pp. 41-50.

Shinn, E.A., 1983. Tidal flat environment. In: Scholle, P.A., Bebout, D.G., Moore, C.H. (Eds.), Carbonate Depositional Environments. AAPG Memoir, vol. 33, pp. 171-210.

Steeman, M.E., 2007. Cladistic analysis and a revised classification of fossil and extant mysticetes. Zool. J. Linn. Soc. Lond. 150, 875-894.

Strohmenger, C.J., Al-Mansoori, A., Shebl, H., Al-Jeelani, O., Al-Hoseni, I., Al-Mehsin, K., Al-Shamry, A., 2004. Modern carbonate-evaporite depositional environments of Abu Dhabi (U.A.E.). Unpublished Field Trip Guide Book, 11th ADIPEC Meeting, First International Evaporite Conference, Abu Dhabi.

Strohmenger, C.J., Al-Mansoori, A. Al-Jeelani, O., Al-Shamry, A., Al-Hosani, I. Shebl, H., Al-Mehsin, K., 2008. The vertical sabkha sequence at Mussafah Channel, Abu Dhabi, United Arab Emirates (Abstract). GEO 2008 Middle East Conference and Exhibition, Bahrain. GeoArabia 13 (1), 241.

Strohmenger, C.J., Al-Mansoori, A., Al-Jeelani, O., Al-Shamry, A., Al-Hosani, I., AlMehsin, K., Shebl, H., 2010. The sabkha sequence at Mussafah Channel (Abu Dhabi, United Arab Emirates): facies stacking patterns, microbial-mediated dolomite, and evaporite overprint. GeoArabia 15 (1), 49-90.

Strohmenger, C.J., Shebl, H., Al-Mansoori, A., Al-Mehsin, K., Al-Jeelani, O., AlHosani, I., Al-Shamry, A., Al-Baker, S., 2011. Facies stacking patterns in a modern arid environment: a case study of the Abu Dhabi sabkha in the vicinity of Al-
Qanatir Island, United Arab Emirates. In: Alsharhan, A., KendallSt.C, C.G. (Eds.), Quaternary Carbonate and Evaporite Sedimentary Facies and Thei Ancient Analogues. International Association of Sedimentologists, Special Publication, vol. 43, pp. 149-182.

Struthers, J., 1888. On some points in the anatomy of a Megaptera longimana, part II - the Limbs. J. Anat. Physiol. 22, 240-282.

Stuiver, M., Reimer, P.J., Reimer, R.W., 2005. CALIB 5.0. [WWW program and documentation].

van Beneden, P.J., 1872. Les baleines fossils d'Anvers. Bull. Acad. Roy. Sci. Belg. Ser. II 34, 6-20.

Warren, J.K., Kendall, C.G.St.C., 1985. Comparison of sequences formed in marine sabkha (subaerial) and salina (subaqueous) settings - modern and ancient. Am. Assoc. Pet. Geol. Bull. 69, 1013-1023.

Wells, A.J., 1962. Recent dolomite in the Persian Gulf. Nature 194, 274-275.

Wood, W.W., Sanford, W.E., 2002. Hydrology and solute chemistry of the coastalsabkha aquifer in the Emirate of Abu Dhabi. In: Barth, H.-J., Böer, B. (Eds.), Sabkha Ecosystems. The Arabian Peninsula and Adjacent Countries, vol. I Kluwer Academic Publishers, Dordrecht, pp. 173-185.

Wood, W.W., Sanford, W.E., Al Habshi, A.R.S., 2002. Source of solutes to the coastal sabkha of Abu Dhabi. Geol. Soc. Am. Bull. 114, 259-268.

Wood, W.W., Sanford, W.E., Frape, S.K., 2005. Chemical openness and potential for misinterpretation of the solute environment of coastal sabkha. Chem. Geol. 215 $361-372$ 